


\section{Contents}

INTRODUCTION: FROM “ISSUES" TO “ARRAYS"

by Stephan Guth and Albrecht Hofheinz

\section{Sample entries}

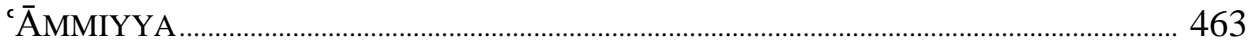

by Eva Marie Håland

BABY MILK

by Albrecht Hofheinz

Clash

by Elena Chiti

CONVERSIONS

by Monika Lindbekk

CROWDFUNDING

by Teresa Pepe

DÉRJA.

by Myriam Achour Kallel and Mariem Guellouz

DUAL IDENTITIES / MASKING

by Stephan Guth

FATHER FIGURES

by Mihaila Yordanova

PSYCHIATRISTS

by Maren Buvarp Aardal

SATIRE (IN YOUTUBE CHANNELS)

by Mohab Mohamed

\section{ز⿳⺈冂大}

ISSN 0806-198X

Journal of Arabic and Islamic Studies • 17 (2017): 455-508 


\title{
Introduction: From "Issues" to "Arrays"
}

\author{
StePhAn Guth and AlbReCHT HofHEINZ (University of Oslo)
}

The following dossier spécial is the outcome of a workshop, held in November 2017 at the Department of Culture Studies and Oriental Languages (IKOS), University of Oslo, to discuss first drafts of entries on the "arrays" in Tunisian and Egyptian everyday life of 2016. The workshop formed part of a 3-year research project, funded by The Research Council of Norway (Norges forskningsråd, NFR) and IKOS, entitled In 2016-How it felt to live in the Arab World five years after the "Arab Spring".

The project's main idea was to take an analytical "one-year snapshot" of life in two countries of the Arab world that had been of particular importance in the context of the socalled "Arab Spring"-Egypt and Tunisia - and to introduce into Middle East Studies an unconventional, innovative approach to how post-revolutionary everyday-worlds were experienced or 'felt': we use fiction (in the widest sense, including cartoons, graffiti, cinema, etc.) and social media 'buzz' published or prominent during 2016 to gain a more intimate understanding of the contemporary Arab world and the people living there. ${ }^{1}$

The project's five main methodological features - the one-year snapshot, the focus on the experience of everyday-worlds, the use of data from several spheres of cultural production, the idea to "let the material speak for itself" by not imposing on it pre-conceived analytical categories, and the presentation of our findings in the form of alphabetically arranged entries, suggesting a non-linear reading guided by numerous cross-references the ensemble of which adds up to a kind of rhizome through which the user will, it is hoped, be able to find his/her own, individual access to these everyday-worlds - these features are inspired by Hans Ulrich GUMBRECHT's seminal "essay in historical simultaneity," the study In 1926: Living at the Edge of Time. ${ }^{2}$ This book provided the model for what our project group was and still is eager to achieve: an approach that allows the reader/user to "jump right into" and move around in the everyday-worlds of the year in question, to pick up its peculiar Stimmung ${ }^{3}$ without too much analytical intervention or interference from the part of those who collected the material. The latter idea seemed particularly important to the designers of the In 2016 project since our target year, unlike Gumbrecht's 1926, was, and still is, not separated from the present by several decades but belongs to a more or less contiguous present. This fact is also mirrored in the "dual identity" or double status of some among the contributors: as researchers on the contemporary Middle East they were/are, on the one hand, observers and analysts with a look "from above" at the everyday-worlds studied as "objects", while on the other hand, they were/are themselves living in these worlds, acting as "subjects", concerned with, involved in, and both formed by and forming these worlds. 
Work on the project began in October 2015. During the "target year," 2016, activities consisted mainly in collecting relevant material ${ }^{4}$ and in assigning preliminary keywords to the data to facilitate search and processing. Towards the end of 2016, in a workshop in November, a first attempt was made to "bundle" pertinent aspects of the extensive data under a number of overarching headings that would have the potential of becoming entries/lemmata in the future publication. These efforts, which were documented in a special dossier of the Journal of Arabic and Islamic Studies the same year, ${ }^{5}$ continued and intensified during the current year, 2017. In regular meetings, the project's core group and associated researchers discussed the collected data in the light of the project's methodological approach and the publication of the research results in the form of a dictionary- or encyclopedia-like monograph, as the print-version of a corresponding website. The main challenge consisted in narrowing down the long list of over 2,750 keywords and issues observed ${ }^{6}$ and transforming them into a new list of terms deemed to be the most suitable 'points of entry' into the world of 2016 and, hence, entries in the future publication.

As in Gumbrecht's In 1926, the entries of our In 2016, too, are of three types: "arrays" (French: dispositifs), binary "codes", and "codes collapsed". ${ }^{7}$ Let us repeat here, for the sake of convenience, the description of these categories as given in the Introduction to last year's Living 2016 dossier:

Arrays are ways in which "artifacts, roles, and activities influence bodies," because these "artifacts, roles, and activities [...] require the human bodies to enter into specific spatial and functional relations to the everyday-worlds they inhabit." ${ }^{8}$ For instance, for the year 1926 Gumbrecht identified the following arrays (my selection):

Artifacts: Airplanes | Assembly Lines | Automobiles | Bars | Elevators | Gomina | Gramophones | League of Nations | Movie Palaces | Mummies | Ocean Liners | Railroads | Revues | Roof Gardens | Telephones | Wireless Communication

Roles: $\quad$ Americans in Paris | Employees | Engineers | Hunger Artists | Reporters $\mid$ Stars

Activities: Boxing | Bullfighting | Cremation | Dancing | Endurance | Jazz | Mountaineering | Murder | Six-Day Races | Strikes

What Gumbrecht calls codes are clusters of arrays that coexist and overlap in a space of simultaneity and "tend to generate discourses which transform [their] confusion into [...] alternative options,", for example:

Codes: $\quad$ Action vs Impotence | Authenticity vs Artificiality | Center vs Periphery | Immanence $v s$ Transcendence | Individuality vs Collectivity | Male vs Female | Present $v s$ Past | Silence vs Noise | Sobriety vs Exuberance | Uncertainty $v s$ Reality

Since such binary codes "provide principles of order within the unstructured simultaneity of everyday-worlds, one might," according to Gumbrecht, "reserve the concept of 'culture' for the ensemble of such codes." 
When the codes lose their de-paradoxifying function, Gumbrecht calls them collapsed codes. Collapsed codes, he says, "are particularly visible because, as areas of malfunction and entropy, they attract specific discursive attention and, often, specific emotional energy." 11 Here are the collapsed codes the author identified for his target year:

Codes Collapsed: Action = Impotence $($ Tragedy $) \mid$ Authenticity $=$ Artificiality (Life) $\mid$ Center $=$ Periphery $($ Infinitude $) \mid$ Immanence $=$ Transcendence (Death) $\mid$ Individuality = Collectivity $($ Leader $) \mid$ Male $=$ Female $($ Gender Trouble $) \mid$ Present $=$ Past (Eternity)

Our discussions regarding which arrays, codes, and codes collapsed should be considered most characteristic for Egyptian and Tunisian everyday-worlds of 2016 are certainly not yet concluded. As of end-2017, we are operating with a list that took shape over the course of our regular meetings and further crystallized during the workshop held in November 2017, which was dedicated exclusively to the discussion of "array" entry drafts. This list contains the following entries:

ARRAYS ("artifacts, activities, or roles that affect human bodies") [NB: entries contained in the present volume are highlighted in bold here]

PAlsh (a parodic technique)

'Ámmiyya (Egyptian Arabic)

Apartment wanted

'Ashwä'iyyāt

Baby milk

Celebrities

Clash / Polarisation

Conspiracy theories

Conversions

Court trials

Crowdfunding

Dancing: see $\rightarrow$ Music

Dérja (Tunisian Arabic)

Disappearances

Disasters

Dollar crisis

Downtown

Dual identities / Masking

Father Figures

Football

Francophonie
Friends

Garbage / zibāla / qumāma

Gated communities / Compounds

Gyms

High school exams

The Honourable Citizen / al-Muwātin al-sharif

In Islam...

Kamīn (informal random checkpoints)

LGBT

Mā-nīsh musāmih (fighting corruption)

Memorial days / Commemoration

Migration

Mobile phones

The Mother of the Hero / Umm al-bațal

Music (incl. Dancing)

New Cafés

Prison

The Police(man) Criminal

Psychiatrists

Red Sea Islands 
Satire (incl. adab sākhir and YouTube channels; possibly to be divided into two or more individual arrays)

Self-censoring

Self-help (incl. exploring the self, authenticity, self-formation, self-help literature)

Social media (Facebook, Twitter)

Suicide

The Suspect Foreigner

Tickling Giants / Pillit adab
Transitional Justice

Tricking the System / Tricked by the System

Tuk-tuk

Uber

Valentine's Day

The Voice from Above (omnipresent propaganda discourses)

Zahma / Crowd (probably including Asphyxia/Suffocation)

As for the CODES, i.e., those "clusters of arrays" that "tend to generate discourses which transform [their] confusion into [...] alternative options" and as such provide "principles of order within the unstructured simultaneity of everyday-worlds" (amounting to what may be conceived of as "culture", see above, p. 506), our preliminary list comprises the following pairs. Question marks "[?]" indicate where we still are particularly in doubt; an additional workshop in spring 2018 will be dedicated to further discussion and clarification, both with regard to appropriate terminology and to assigning phenomena and issues observed to the terms agreed upon. In some instances, the reader will find additional information after a vertical line "|", indicating alternative names under discussion. Parentheses are also used to remind us of a number of issues/phenomena that may "belong" to the code in question.

\section{Affluence $v s$ Destitution}

Beautiful vs Ugly (incl. Clean-pure $v s$ Dirty-filthy, Culture [as Humanism] vs Barbarism | re-enchantment; ...)

Culture vs Politics | Healthy vs Unhealthy (dehumanisation)

Center vs Periphery (incl. City vs Compound, 'Ashwä'iyyāt vs Center; Provinces vs Big cities, esp. the Capital)

Egypt/Tunisia vs Barra

Egypt vs Tunisia

Freedom vs Constraint

Hope vs Despair

[?] Idea vs Practice (Letter/rules/principles vs Application, "Spirit of the laws" vs Non-implementation)

Individual vs Collective/Community,
Individuality vs Collectivity (incl. "Public morals" and space, freedom $v s$ constraint, individual freedom $v s$ al-mașlaḥa al- 'àmma, egotism vs altruism/solidarity, "Schicksalsgemeinschaft", sense of duty, ir-/responsibility, etc.)

Male vs Female / Man vs Woman

Normality $v s$ Heroism

Past vs Present (Continuity vs Change)

Private vs Public (taxi; new cafes; as a space where public and private intersect; street)

[?] Right $v s$ Wrong (moral normativity, $m \bar{a}$-yiṣaḥh-ish kidā)

Security vs Fear | Stability vs Freedom/ Democracy

Superiority vs Inferiority | Victory vs 
Introduction: From "Issues" to "Arrays"

Defeat

"The System" vs "The People" (incl. Deep state)

True $v s$ False

Voice vs Silence ("Who has a voice in the country?", Freedom of expression $v s$ self-censoring, + Rant)

Wațan vs Ghurba

Young vs Settled

What was said about the Codes - still work in progress- holds true perhaps even more so for the CODES COLLAPSED, i.e., those that have lost their de-paradoxifying function and are now "particularly visible because, as areas of malfunction and entropy, they attract specific discursive attention and, often, specific emotional energy" (see above, p. 506). There remain even more open questions here than in the case of the Codes, and the list we shall end up with in our In 2016 publication later in 2018 will mirror our opinion on how deep the Revolutions really have shattered Egyptians' and Tunisians' worldviews: can we really speak of "collapsed" codes, codes that have lost their de-paradoxifying function and point to areas of malfunction? In some cases, it looks as if, in spite of the Revolutions, people in 2016 still conceive of their worlds with categories that are not so different from earlier ones. Often, codes still appear to provide meaningful options rather than having become meaningless, "neutralized" by each other. In other cases, however, collapsed codes may indeed have generated new "states of matter," express new configurations and ways of perception. Here is the list that reflects our current state of discussion (end-2017):

[?] Hope = Despair/Hell (Dystopia) $(i k t i ' a \bar{b}$; frustration; apocalypse; apocalyptic descriptions of the end of the city, both in novels and in television shows; environmental dystopias: earthquakes, desertification; horror fiction; Trump; global war; dehumanisation; upholding humanity) $\mid$ Future = No Future (Dystopia). - It seems to be quite clear that we are dealing with a collapsed code here, but we are still undecided on whether it should be merged with, or be kept apart from, the following:

Past $=$ Present (Stuck) (blocked energy/dreams/hope; as in social media and youth's cultural productions; activists' ikti'âb, ta'ab, "I can't leave but I can't stay"; maznūqīn / asphyxia, țarīq masdūd; kamīn; nafsinā itsaddit; related also to Wațan = Ghurba; frustration / ihbāt, sense of defeat, see Victory vs Defeat; political demobilization, "we withdrew from politics"; also related to rant; cf. also Gumbrecht's "Action = Impotence (Tragedy)".

Normality = Heroism (Surviving) (the Ordinary citizen as Hero; Managing / mastering everyday life) | Lack of Resources = Resourcefulness (Ibtikār). NB: We may be dealing with a secular(ized?) version of "martyrdom" here, so perhaps the equation is "Defeat = Superiority (Citizen heroism)" or "Powerlessness = Strength (Citizen heroism)".

Security $=$ Fear $\mid$ Order $=$ Chaos $($ Police State $)$

[?] State $=$ People (Patriotism)

Wațan $=$ Ghurba $($ Alienation $)$ 
We also have a brief list of ISSUES, i.e., topics/phenomena that appear important but where we have not yet come to a conclusion on how to deal with them within the Arrays/Codes/Codes Collapsed framework (such as Azma; Dream/Imagination vs Reality; Environment, nature and pollution; Escaping/Get out of here; Suez Canal). Further discussions will determine how to deal with these phenomena.

In its current state, our list of arrays, codes, and codes collapsed provides a preliminary snapshot of our discussions that we are publishing here to document our work in progress. We hope that the entries presented below may inspire others to join in the creation of the "encyclopedia of how it felt to live in the Arab World five years after the "Arab Spring".

(C) Stephan Guth \& Albrecht Hofheinz Dept. of Culture Studies and Oriental Languages, University of Oslo / Norway \ stephan.guth@ikos.uio.no|albrecht.hofheinz@ikos.uio.no 


\section{‘Āmmiyya}

(..) bridging the big gap that has emerged between our language of today and the essential works (ummahāt al-kutub) of literature, the heritage and the language and style they were written in (...) for the language not to be a monopoly for those who studied it and understand it (...) so that it is possible for a twelve or thirteen, or even younger boy or girl, to read one of the essential works and understand what is being said (...) that it is natural and happens in any language (...) personally I think that no awakening/revival/renaissance (nahda) will take place in the Ar$\mathrm{ab}$ countries unless we know how to understand our forefathers first. (al-Ma'arrī 2016: $7-8)^{1}$

These points are listed as motivations for why the Egyptian scholar, translator and novelist Nārīmān al-Shāmilī (b. 1983) chooses to translate Abū 'l-'Alā' al-Ma'arrī's Risālat alghufrān ("The Epistle of Forgiveness") into Egyptian 'āmmiyya (vernacular Arabic). It is most likely the only translation published this year from fuṣha (standard Arabic) to 'āmmiyya. However, use of 'ammiyya in writing is not rare: billboards decorating buildings and roadsides are often in 'ammiyya, which is also frequently used on social media [ $\nearrow$ Social Media]; Egyptians receive text messages from their telephone companies in 'āmmiyya [ $\nearrow$ Mobile Phones], and books are being published that are written fully or partly in 'ámmiyya, or in a mix between 'ámmiyya and fuṣhā. Many of them belong to the adab sākhir genre [ $\nearrow$ Satire], such as Ghayr qābil li'l-nashr ("Unpublishable") by Sharīf As'ad, or even self-help books [ $\nearrow$ Self-help] such as Il-Khurūg 'an il-nașs ("Out of the Box") by Egyptian psychiatrist Muḥammad Țāhā [ $\nearrow$ Psychiatrists]. Muhammad Ibrāhīm's book Maṭlūb habīb ("Sweetheart Wanted") is labelled i'tirāfāt ("confessions"). As many writers before him, he raises the dilemma of which variety to write in:

I have grown up but I have not really grown up...I have grown up but I still write 'ammiyya next to fușhā...I know that it is better if the book is all in fuṣhā, but I prefer to express myself in 'ammiyya, I was born and raised in a country which speaks in a variety (lahga) which is different from the official variety (lahga) that is written in books and in education. I learned in one way and lived in another. I cannot define my identity closer to any of the varieties...both of them represent me... a variety closer to my intellect ( ${ }^{\prime} a q l$ ) and a variety closer to my heart and way of life...for this reason I decided to complete the book using both varieties" (Ibrāhīm 2016: 10).

Moreover, the Egyptian president [ $\nearrow$ Father figures] gives formal speeches in ' $\bar{a} m$ miyya and uses several linguistic features that are not associated with the prestige register of 'āmmiyya. On October 6, the Facebook page Asa7be Sarcasm Society posts a meme involving an image from a news broadcast showing al-Sīsī commemorating the $43^{\text {rd }}$ anniversary of the October War together with the Sudanese President 'Umar al- 
Bashīr [ $\nearrow$ Commemorations]. The caption reads iddīhā wāḥda tahya à Masr/Misr, which literally means "Give it a "Long live Egypt." The word for Egypt is spelled with the letter $\sin$ instead of the correct $s \bar{a} d$, mocking the president's 'weak' pronunciation. Imitation or mocking of specific pronunciations is often found when 'ämmiyya is written. On November 1, a meme posted on the same Facebook page targets certain women who speak in a flirty/childish/spoiled manner. This time it is an image from the movie 'Asal iswid ("Black Honey") from 2010. The original scene involves the protagonist, called Mașrī (i.e., "Egyptian"), who has returned to Egypt after twenty years in the United States, his friend $\mathrm{Sa}^{c} \overline{1} \mathrm{~d}$, and Mervat, the woman $\mathrm{Sa}^{\mathrm{c}} \overline{\mathrm{i}} \mathrm{d}$ is in love with. Mervat is a primary school teacher of English, and Mașrī is provoked by her faulty English: she pronounces /f/ for /v/, /b/ for /p/ etc. The author of the meme turns the focus over to Egyptian 'âmmiyya, adding the following caption:

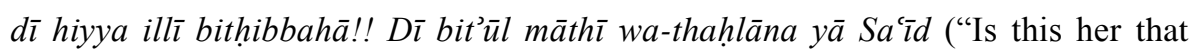
you love!! She says māthī and thahlāna, Sa'̄īd!").

Māthī is a variant of $m \bar{a} s h \bar{\imath}$ (lit., "it goes", i.e., "o.k."), and thaḥlāna of za'lāna (the feminine form for "sad"). The post generates comments of which some contain new memes treating the same topic. One of these is an image from a different movie, in which a woman is portrayed as saying shha'üllak kita baqā zahlāna minak. This would, according to the conventions, be written mish ha'üllak kida baqā za'lāna minak ("I'm not going to tell you, I am angry with you"). Yet, this particular transcription points to specific linguistic feautures - those of flirty/childish/spoiled/lower class women-which are immediately recognized as communicating a social meaning. Such meanings are often linked to certain speech groups or strata of society [ $\nearrow$ Affluence $v \boldsymbol{s}$ Destitution], or a specific person or character [ $\nearrow$ Celebrities].

\section{Related Entries}

Arrays: Celebrities; Commemorations; Father figures; Mobile Phones; Psychiatrist; Satire; Self-help; Social Media • Codes: Affluence vs Destitution

\section{References}

Print

al-Ma'arrī, Abū al-`Alā’ 2016. Risālat al-ghufrān / translated by N. al-Šāmilī. Al-Qāhira: Al-Kutub Khān.

Muḥammad Ibrāhīm. 2016. Maṭlūb ḥabīb. al-Qāhira: Dār Dawwin.

Muhammad Ṭāhā. 2016. Il-Khurūg 'an il-nașs. al-Qāhira: Dār Tūyā.

Sharīf As`ad. 2016. Ghayr qābil li’l-nashr. al-Qāhira: Dār Tūyā.

\section{Memes}

Muhammad Durgham, posting on Asa7be Sarcasm Society, October 6, 2016, <https://www.facebook. com/asa7bess/photos/a.263636427064801.58209.263629920398785/1285512081543892>（retrieved October 27, 2017).

jais • 17 (2017): 463-465 


\section{ARRAYS ‘Āmmiyya}

Muhammad 'Āṭif, posting on Asa7be Sarcasm Society, November 1, 2016, <https://www.facebook. com/asa7bess/photos/a.263636427064801.58209.263629920398785/1310753782353055>（retrieved October 27, 2017).

N.N., posting on Asa7be Sarcasm Society, November 1, 2016, <https://www.facebook.com/photo. php?fbid=1171521389596682\&set=p.1171521389596682> (retrieved October 27, 2017).

(C) Eva Marie Håland, Dept. of Cultural Studies \& Oriental Languages, University of Olso / Norway ४ e.m.haland@ikos.uio.no 


\section{Baby Milk}

On September 2, the hashtag \#laban_al-'askūr explodes on social media [־Social Media]. It is tempting to translate this as \#cop_milk to reflect the wordplay, in Arabic, on laban al'asfür 'crop milk', an Egyptian expression denoting the unimaginable and impossible. Birds are not mammals, after all. Most people are surprised to learn that 'bird's milk' (the literal rendering of laban al-'asfür) really does exist-both al-Ahrām and Wikipedia attest to this unheard-of natural phenomenon. And ordinary citizens are just as stunned to learn of the 'arMY milk' (another attempt to translate laban al-'askūr) that the Egyptian military is ready to provide in order to defuse citizens' anger when subsidised infant formula suddenly turns all but out of reach for average Egyptian families. The army has 30 million canisters of toddler milk stored in their barracks? Why? What for? Apparently, the nation's foremost institution really does want to make sure it can steer its subjects from the cradle to the grave. And " 20 years from now," one of the first tweets predicts, they will yell at you, "you dare insult the army that taught you and suckled you? \#Badr_International_School \#laban_al-'askür". This tweet combines reference to the toddler milk affair with a stab at the school the military established a year ago to attract well-paying youngsters $(20,000$ EGP for a kindergarten place) away from private international schools, and to provide them "the weapons of education necessary for their future endeavors." Badr School is facing a backlash as it embarks on its second year, with people objecting to the military's engagement in yet another socioeconomic sector. While critical voices question both the motives and the ability of the military to manage what should be civilian affairs, others take less issue with that. "The military is running all of Egypt, why would I be concerned about it running a school?" says a mother of two kids there. Many do believe that the products and services the military delivers really are better than what others have to offer. Yet this belief becomes the object of derision as well. "They say that Badr School is whiter than white," Abla Fāhītā, the wildly popular Egyptian muppet character, tweets on Aug. 29. Why? "They constantly sweep the floor there with the General" detergent. Can anyone object to using General ("Max Clean, Max Fresh") to secure, as the commercial promises, an "Ultimate clean house"? [ 7 Satire] It is not easy to ascertain who at any one moment has the upper hand in this war of words. For many-teachers and parents at Badr School, drivers filling gas at the Wataniyya patriotic petrol stations, consumers buying fruit and eggs, noodles and refrigerators produced in military-owned farms and factories, the sick placing their hopes on drugs and medical equipment imported by the military, and for countless others- the military represents a force serving the nation rather than individual private interests. Protests against the military's role are therefore often regarded as being the result of a conspiracy directed from abroad, and thus Badr's school principal reveals in an interview with MadaMasr that

There's a fortune teller in America whose prophecies all come true. He predicted that in one of the Arab countries there will be a president who pretends to represent 
Islam, though he is far from it [a reference to deposed president Mursī] and that the president who comes next would unite the Arab region and destroy the American economy. That president will have a name made up of two repeated syllables [he means Sisi]. [ $\nearrow$ Conspiracy Theories, $\nearrow$ Superiority vs Inferiority, $\nearrow$ Suspect Foreigner]

It is in such a climate that the baby milk crisis erupts. When women on August 31 suddenly and without prior warning find they no longer can buy infant formula at the subsidised price of 5-17 EGP but are being referred to the open market where the cost of a canister quickly rises to 60-70 EGP, they are shocked and pour their anger into street demonstrations catching media attention. The women and their families find themselves confronted with a fait accompli as no one has prepared them for the Health Ministry's decree tighten-

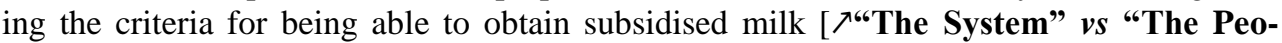
ple"]. The Ministry, for its part, is merely trying to help "stem the subsidy haemorrhage," to contribute to the overall fiscal consolidation that the IMF requires to approve its biggest ever Middle East loan (12bn USD over 3 years, 4 times as much as Sisi's predecessors dared to ask for) [ $\nearrow$ Dollar Crisis]. This grander order of things is lost, however, on countless women who complain that they now no longer know how to feed their babies [ $\nearrow$ Affluence $\boldsymbol{v s}$ Destitution]. At this point, the army is there to save them. To counter what it describes as "monopolistic practices by pharmaceutical companies" (and without mentioning that the main company involved is the state-owned Egyptian Pharmaceutical Trading), the Armed Forces promise to deliver 30 million canisters of baby milk-half of Egypt's annual demand-to be sold at pharmacies for "no more than 30 EGP" [ $\nearrow$ The Voice from Above]. A few observers point out that this is twice the expense incurred for importing the milk, meaning a net profit of 450 million EGP "for a tiny crisis created in just one day" (coincidentally, this corresponds exactly to the amount, c. 51 million USD, that the Ministry of Health claims it uses per year for supplying infant formula) [ $\nearrow$ Tricked by the System]. But such nit-picking cannot deter the authorities. Soon, fleets of trucks bearing the message "Don't pay more than 30 pounds!" appear on streets and newspaper pages, and "France Lait" canisters labelled "Long live Egypt... with regards, The Armed Forces" hit the shelves. A pernickety tweep notes that these army-branded milk canisters bear a production date going back a month before the outbreak of the shortage [ $\nearrow$ True $\boldsymbol{v s}$ False], but further speculations on who created the emergency are drowned by social media outrage at another scandalous aspect of the issue. For the Ministry of Health follows the army in the attempt to defuse the crisis, softening its decree to give access to the subsidised substitute not only in cases where the mother is completely unable to breastfeed, but also where she does not produce enough mother's milk of her own. To prevent abuse of the system, women now have to undergo a breast examination before being handed out the subsidised formula. While the banned Muslim Brotherhood tries to exploit the issue in their broadcasts from abroad, claiming that the regime is forcing women to undergo breast examinations in public - a claim strongly denied by the authorities - other commentators draw parallels to the army's earlier practice of carrying out 'virginity tests' on female demonstrators. As if to confirm that a patriarchal mindset dominated by a view of woman primarily as reproductive sexual bodies that need to be contained and controlled, still runs deep, a member of parliament publicly declares, the same day the baby milk affair breaks, 
his opposition to a legislative amendment harshening the punishment for performing female genital mutilation. Egypt's "men suffer from sexual weakness," he explains. "For the sake of equality between men and women, women should therefore be circumcised to reduce their sexual desire." [ $\nearrow$ Male vs Female]

Such an 'extreme' formulation is no longer a matter of consensus in Egypt (even though it can still frequently be encountered on social media); neither is the same parliamentarian's call to introduce virginity tests for girls wanting to enter university. Nevertheless: sexual harassment and gendered violence remain rampant and constitute an important framework for how women are treated and have to comport themselves. Just how important is indicated by the way the affair is framed when it becomes a buzz issue on social media, to the extent that it is picked up by the Arabic HuffPost under the headline "Medical Examination of the Mothers of Egypt on the Street". Criticism of the political economy of things is drowned out by moral outrage; and this moral outrage is less about the state subjecting its citizens' bodies to humiliation, but over the allegedly public breast examinations, i.e. the public exposure of women's bodies that are supposed to remain hidden from view [ $\neg$ Mother of the Hero]. Small wonder that the 'shame' of breastfeeding in public is one of the main reasons for why $60 \%$ of Egyptian women rely on infant formula in the first place.

\section{Related Entries}

Arrays: Conspiracy Theories; Dollar Crisis; Male vs Female; Mother of the Hero; Satire; Social Media; The Suspect Foreigner; The Voice from Above; Tricked by the System Codes: Affluence vs Destitution; Superiority vs Inferiority; "The System" vs "The People"; True $v s$ False

\section{References}

Abla Fahita (@ AblaFahita), "Biyqūlūlī Madāris Badr International School dī naḍifa fulla... 'alā țūl biyimsaḥū 'l-arḍ bi'l-Generāl,' Twitter, August 29, 2016, <https://twitter.com/AblaFahita/ status/770262197469638656>.

“About BIS”, Badr International Schools, 2016, <http://www.bis-eg.com/About\%20BIS.aspx?id=2>, accessed November 13, 2017.

'Afĩfĩ, Hiba, “'Madā Mașr' fī ziyāra maydāniyya li-madrasat al-quwwāt al-musallaḥa al-duwaliyya," MadaMasr, September 7, 2016, <https://www.madamasr.com/ar/2016/09/07/feature/

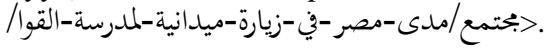

Ahmed Anwar (@A7mdAnwar), “*Bacd 20 sana* [...]”, Twitter, Sep. 1, 2016, 7:53 p.m., <https://twitter.com/A7mdAnwar/status/771405683422031872>.

Dāliyā 'Uthmān, "al-Ğaysh yatasallam awwal shaḥna min albān al-aṭfāl: «mā tidfa'sh aktar min 30 Ğinēh» (șuwar)”, al-Mașrī al-Yōm, September 19, 2016, <http://www.almasryalyoum.com/news/ details/1011013>.

“Egyptian MP Referred to Ethics Committee for Supporting FGM Due to 'Sexually Weak Men'”, Egyptian Streets, September 9, 2016, <https://egyptianstreets.com/2016/09/09/egyptian-mpreferred-to-ethics-committee-for-supporting-fgm-due-to-sexually-weak-men/>.

"Faḥ̣ țibbī li-ummahāt Miṣr fî 'l-shāric... khulūw al-thady min al-laban sharṭ șarf halī̄ al-aṭfāl almuda"am", Huffington Post 'Arabī, September 8, 2016, <http://www.huffpostarabi.com/2016/09/ 08/story_n_11904302.html>. 
Feteha, Ahmed and Andrew Mayeda, "IMF Approves Biggest-Ever Mideast Loan to Revive Egypt's Economy," Bloomberg, November 11, 2016, <https://www.bloomberg.com/news/articles/201611-11/imf-approves-biggest-ever-mideast-loan-to-revive-egypt-s-economy>.

Ghāda Ibrāhīm, "Af̣̣al munaḍḍif li’l-sērāmīk," al-Mirsāl, April 5, 2015, <https://www.almrsal.com/ post $/ 225523>$.

El-Gizawi, M. (@MElGizawi), “Fākrīn azmit \#laban_al-ațāâl wi'l-ẓuhūr il-sarīe li \#laban_al-'askūr?! [...]", Twitter, September 23, 2016, 4:12 p.m., <https://twitter.com/MElGizawi/status/779322 505282588672>.

"Got Milk? Egypt to Check Women's Breasts Before Supplying Baby Formula," Middle East Eye, September 7, 2016, <http://www.middleeasteye.net/news/got-milk-egypt-wants-check-women-sbreasts-supplying-baby-formula-1819401048>.

"Halīb al-ḥawșala", Wikipedia, <https://ar.wikipedia.org/wiki/حليب_الحوصلة, accessed 13 November 2017>.

Huwayda 'Abd al-Ḥamīd, "«Laban al-'așfūr»” ḥaqīqa am khayāl?!”, al-Ahrām al-Zirā̄ec, 6 April 2016, $<$ http://agri.ahram.org.eg/News/22948.aspx.

"Ilhāmī 'Ağīna yuțālib bi-kashf țibbī li-ithbāt 'udhriyyat al-banāt ka-shart li'l-qubūl bi'l-ǧāmi'āt," al-

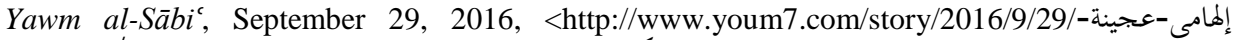
2902061/يطالب-بكشف-طبى-لإثبات-عذرية-البنات-كشرط-للقبول> >

Moghazi, Amr (@AmrMoghazi5), “\#Laban al-'askūr wașal [...]”, Twitter, September 21, 2016, <https://twitter.com/AmrMoghazy5/status/778520809790930944>.

Muhammad Șubḥ̄i, "Riğğālit Maṣr 'andahā dụ f ğinsī... Ilhāmī 'Ağ̄ina: lāzim il-sittāt tirḍā bi'l-khitān 'alashān il-'ağala timshī’, Barlamān̄̄, September 1, 2016, <http://parlmany.youm7.com/News/5/ > رجالة-مصر-عندها-ضعف-جنسى-إلهامى-عجينة-لازم-الستات-ترضى/2019212.

"Need Baby Milk? You'll Need a Breast Exam First, Says Egyptian Health Ministry", Middle East Eye, September 12, 2016, <http://www.middleeasteye.net/in-depth/features/need-baby-milkshow-us-your-breasts-says-egyptian-health-ministry-subsidised-women-military-986760374>.

Qanāt al-Sharq, "Haytham Abū Khalīl ba'da kārithat al-kashf 'alā thady al-ummahāt ka-sharṭ li-ṣarf laban al-ațāă...āh yā nakhkhāsīn yā huthālā!...," YouTube, Sep. 5, 2016, <https://youtu.be/ 8IPB3-COIPo>.

al-Sa'danī, Rabī', "Ḥaqīqat faḥṣ «athdā̄ al-ummahāt» fì Marākiz al-Usra... wa'l-Șiḥḥa: sharṭ li'lhușūl 'alā 'l-albān," al-Tahrīr, September 9, 2016, <http://www.tahrirnews.com/Posts/printing/

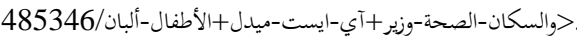

al-Sharika al-Mișriyya li-Tiğārat al-Adwiya, updated June 30, 2016, <http://www.eptc-egydrug. com>, accessed November 13, 2017.

al-Thawra Tağma'unā, "Infōgrāf || Laban al-'askūr," YouTube, September 5, 2016, <https:// youtu.be/F16PYK3dhiI>.

(C) Albrecht Hofheinz, Dept. of Cultural Studies \& Oriental Languages, University of Oslo / Norway

\ albrecht.hofheinz@ikos.uio.no 


\section{Clash}

Al-'adāla li'l-jamī' ("Justice for all") runs the slogan of a huge banner in a cartoon drawn by Andeel. ${ }^{1}$ However, the Egyptians rallied under it seem to have different views of what "all" should include. Everyone has his or her own exception to the rule. "Except women," an old man says. "Except my stepdad," says a veiled girl. "Except child molesters," a weeping child begs. And the exclusion goes on: "except rich people," "except taxi drivers." On the left, a policeman in uniform adds: "except the terrorist sons of a whore," while stealing a glance at a bearded man wearing a gallabiyyah. "Except the infidels," replies the latter. The black uniform and the white gallabiyyah, placed next to one another, attract attention as if pointing to a clash within the clash: while the rest of the society seems to engage in a chaotic battle of everyone against everyone, the policeman and the Islamist fight against each other. [ $\nearrow$ Male $v \boldsymbol{s}$ Female; $\nearrow$ Affluence $v \boldsymbol{s}$ Destitution; $\lambda$ Security $v$ s Fear; $>$ Security $=$ Fear $($ Police State $) ;>$ In Islam... $]$

In the English translation of the cartoon's captions, the policeman is called a "policeman," while the bearded man is labelled an "extremist". "Extremism (tatarruf) can only be fought through culture," repeatedly say the organisers of the $47^{\text {th }}$ edition of the Cairo Book-Fair. ${ }^{2}$ Its slogan this year is al-Thaqāfa fì'l-muwājaha ("Culture on the frontline"), ${ }^{3}$ where culture stands for the state's secularism and the frontline for the war against extremism. ${ }^{4}$ The meaning is constantly explained during the panel discussions hosted by the Book-Fair. "Culture is the key to democracy," states Nabīl 'Abd al-Fattāh, author of essays on Islamism and former co-director of al-Ahrām Centre for Political and Strategic Studies: "And democracy has to flourish in spite of the people who are convinced that a religious expertise provides the key to hold the truth." The audience applauds. "Culture is the conviction that there is no such thing as absolute truth," confirms $\mathrm{Sa}^{\mathrm{c}} \overline{\mathrm{i}} \mathrm{d}$ Tawfìq, professor at Cairo University and former Secretary General of the Supreme Council of Culture: "Truth is always relative. That is why the Muslim Brotherhood had to be defeated. ${ }^{5}$ [ $\nearrow$ In Islam...; $\nearrow$ Victory vs Defeat]

All the Egyptians recall the summer of 2013 when the Muslim Brotherhood was defeated, after massive demonstrations that led to the removal of president Morsi by the army of general Sisi on July 3. Yet, the recollection does not awaken in everyone the same feeling. While institutional voices celebrate it as a victory of democracy and culture, the members of the defeated party see it as an unjust takeover. That summer, they organised a huge sit-in protest in Rabaa al-Adawiya (Rābica al-'Adawiyya) Square, in northeastern Cairo, which was violently dispersed by the police on August 14, with at least 817 people killed. "On this day three years ago, my 21-year-old sister was murdered in cold blood. I knew then that I no longer belong here," reads a post by a 28 -year-old man. ${ }^{6}$ Blogger and activist Alaa Abdel Fattah ('Alā' 'Abd al-Fattāḥ) also recalls 2013, saying it was the beginning of "a poisonous polarisation between a rabidly militarised pseudo-secular statism and a viciously sectarian-paranoid form of Islamism". ${ }^{7}$ [ 7 The Police(man) criminal] 
The movie Ishtibāk (Eshtebak / Clash), too, is set in the summer of 2013, within a police truck where pro-Morsi and anti-Morsi demonstrators are put together after being arrested [ $\nearrow$ Prison]. The camera never leaves the truck, which comes to contain a sample of the Egyptian population: men and women of different generations, social classes and political affiliations, who usually oppose each other in daily life. Mutual understanding is only possible within the narrow space of the truck, thanks to the intimacy they are forced to. The director, Mohamed Diab (Muhammad Diyāb), says Clash is a call for mutual understanding, beyond the internal divide of the Egyptian society: "I want people to watch my movie without asking what side I belong to." ${ }^{8}$ He claims to be neither with the Muslim Brotherhood nor with the army, but with the people who stand against polarisation. He explains how difficult it was to take this stand in Egypt: he could hardly find Egyptian investors, afraid of a political subject, and had to turn to European coproducers. 9

Europe warmly welcomes Clash, the only Egyptian film screened at Festival de Cannes. There, on the red carpet, Egyptian Muslim preacher and TV star Moez Masoud (Mu'izz Mas' ${ }^{\mathrm{u}} \mathrm{d}$ ) poses with the cast, revealing through a tweet his financial participation in the production. His followers thank him, talking about a Muslim commitment for the sake of Egypt. "This is the right path (il-tarīq il-șahh)!" a lady writes, echoing the title of a successful TV show in which Masoud teaches how to deal with life in the Islamic way ${ }^{10}$ [ $\nearrow$ In Islam...; $\nearrow$ Self-Help]. On the other side, Egyptian institutional voices manifest their indignation. The TV show Anā Mașrī ("I am Egyptian"), on state-owned Nile TV channel, depicts Diab as follows: "Mohamed Diab is a young man who graduated from a faculty of commerce and worked for foreign banks and, in this period, he presented himself as a political activist (...). In 2005, he suddenly switched to cinema studies at New York Academy," and in 2010, with his movie on sexual harassment, he started "giving a distorted picture (șüra mushawwaha)" of Egypt. ${ }^{11}$ The extent of his contacts with foreign institutions is emphasized to make him look like a suspicious individual who favours anti-Egyptian interests [ $\nearrow$ The Suspect Foreigner].

In Egypt, many cinemas refuse to screen the movie and a Facebook campaign-Id'am haqqak innak tshüf Ishtibāk ("Support your right to watch Clash")—is launched in response. Mohamed Diab publishes on his Facebook page the photo of a letter of solidarity, signed by Hollywood star Tom Hanks: "Few Americans see Egypt as being anything more than terrorists and pyramids. Your film CLASH will go great lengths to enlighten many." And he adds in Arabic: "Daniel Craig, hero of James Bond's movies, also sent me a similar letter, which means the opposite of staining the reputation of Egypt"12 [ $>$ Social Media]. When the movie is finally screened, the Egyptian audience discovers it contains an initial warning that closely recalls institutional propaganda: "After the June $30^{\text {th }}$ revolution, the Muslim Brotherhood provoked bloody clashes to prevent the peaceful transition of power" [ $\nearrow$ The Voice from Above]. The responsibility for violence is shifted onto the Muslim Brotherhood, while the other side is associated with peace.

An article titled "Mā lā yacrifu-hu Tom Hanks" (What Tom Hanks ignores) states that the positive depiction of the policemen, throughout the movie, is a deliberate distortion of reality. It can be mistaken for real by Hollywood, not by an Egyptian eye that saw the police in action. ${ }^{13}$ Another article provocatively asks: "Ma'a man nashtabik idhan?" (With whom do we clash then?) It also criticizes the positive representation of the police, 
exemplified by the officer kindly advising a lady not to join the demonstrations: "Does such a police officer not exist in reality? Of course he does, but when you release a work in which everything becomes a symbol, the presence of a similar model naturally turns into a propagandistic attempt of cleaning up the image of the whole category. Before a cancerous body, do not ask me to notice the whiteness of the teeth!"14 For the author of the article there is no such thing as a call to overcome polarisation in the movie, only the recommendation to stop protesting and choose the stability granted by the police: "What does distinguish the narrative of this movie from the narrative of the propaganda?" he ends up asking. And the clash over Clash goes on, revealing not only the divide between supporters of the Muslim Brotherhood and supporters of the state, but also between the latter and the people who, considering it a police state, would not chant (anymore) the slogan "The police and the people hand in hand." [ $\nearrow$ The Police(man) criminal; $\nearrow$ True vs False; $\nearrow$ Security = Fear $($ Police State $) ; \nearrow^{\prime \prime T h e ~ S y s t e m " ~ v s ~ " T h e ~ P e o p l e "] ~}$

\section{Related Entries}

Arrays: In Islam; The Police(man) criminal; Prison; Self-Help; Social Media; The Suspect Foreigner; The Voice from Above - Codes: Affluence vs Destitution; Male vs Female; Security vs Fear; "The System" vs "the People"; True vs False; Victory vs Defeat $\downarrow$ Codes collapsed: Security $=$ Fear (Police State)

\section{References}

Amin, Shahira. "Three years on, wounds of Egypt's deadly sit-in dispersals linger." Al-Monitor, August 21, 2016: <https://www.al-monitor.com/pulse/originals/2016/08/egypt-three-yearanniversary-rabaa-sit-in-brotherhood.html>.

Anā Maṣrī [TV show]. Ḥalqat "Fīlm Muḥammad Diyāb Ishtibāk, bi-nakha siyāsiyya wa-thawriyya", May 15, 2016: <https://www.youtube.com/watch?v=SiwWQxmP5WQ>; see also: <https://www. youtube. com/watch?v=-lmutjpDCBA>.

Andeel, “Al-'adāla li'l-jamīe." Mada Masr, 11 February 2016: <https://www.madamasr.com/en/ 2016/02/11/cartoon/u/justice-for-all/>.

Faraj, Sāmiḥ. "Ințibāāāt sarî‘a 'an fîlm Ishtibāk", Za2ed18, July 31, 2016: <http://www.za2ed18.

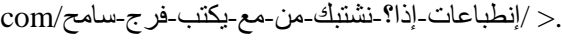

“"I was terribly wrong'—writers look back at the Arab spring five years on.” The Guardian, January 23, 2016: <https://www.theguardian.com/books/2016/jan/23/arab-spring-five-years-on-writerslook-back>.

“Ishtibāk: fîlm miṣrī fì iftitāḥ mahrajān Kān [Cannes]." al-Ahrām, May 13, 2016: <http://gate. ahram. org.eg/News/978271.aspx>.

Masoud, Moez [Mu'izz Mas'ūd]. <https://twitter.com/moezmasoud/status/730910281442971649>.

Midḥat, Aḥmad. "Mā lā yárifu-hu Tom Hanks," Masralarabia, July 30, 2016: <http://

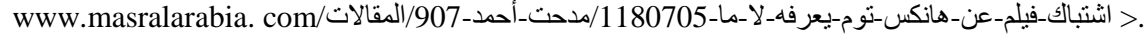

Sotinel, Thomas. "Clash : après le bus 678, le fourgon de police." Le Monde, May 12, 2016: $<$ http://www.lemonde.fr/festival-de-cannes/article/2016/05/12/clash-apres-le-bus-678-le-fourgonde-police_4917875_766360.html>.

“Tajribatu-hu maca 'l-Ikhwān fị ḍayf al-sharaf.” Akhbār al-Adab, February 14, $2016: 6$.

al-Thaqāfa fì 'l-muwājaha. Round Table discussion, Cairo Book-Fair, Main Hall, January 29, 2016.

jais • 17 (2017): 470-473 
"Tom Hanks and Daniel Craig Express Their Love for Egyptian Movie 'Eshtebak'." Scoop Empire, July 26, 2016: <http://scoopempire.com/eshtebak-tom-hanks-daniel-craig/>.

“Al-yawm... ințilāq ma rạ̣ al-Qāhira li'l-kitāb.” Al-Shurūq News, January 27, 2016: <http://www. shorouknews.com/news/view.aspx?cdate $=27012016 \& i d=f e 442$ bc5-e180-45fa-afaa$745 f 748240 \mathrm{bf}>$.

(C) Elena Chiti, Dept. of Cultural Studies \& Oriental Languages, University of Olso / Norway

$\triangleleft$ elena.chiti@ikos.uio.no 


\section{Conversions}

On August 4, Muḥammad Higāāī, an Egyptian in his early thirties, appears in a video uploaded to YouTube [ $>$ Social media] looking pale but composed. In a well-rehearsed statement, he publicly blesses the Prophet Muhammad as "the foremost among Allah's creation" and also spells out the shahāda, the Islamic proclamation of faith. With this, Higāzi - until then Egypt's 'best-known convert from Islam' who had become Christian and taken the name Bishōy-reverts to Islam. The video ends a nine-year-long struggle with courts and other authorities to be legally recognized as a Christian. (Back in 2007, he had filed a lawsuit to try to change his religious identity as shown on his ID card from "Muslim" to "Christian"). In the video, Higāzī apologizes to his family and says he will never again speak to the media:

I want nothing from this video. I have no desires. I will not appear again in the media. I will not appear again publicly. [...] I say this out of my complete free will. I am under no pressures from anyone. I am not being held by any agency, nor am I under any pressure of any kind. And that's it. ${ }^{1}$ [ $/$ Freedom vs Constraint]

Religious conversion is a multi-faceted phenomenon with personal, cultural, social, and religious implications. Muhammad Higāzī’s story highlights some of the more quotidian aspects of conversions, namely how the Egyptian state inserts itself into religious life. Changing one's religion in official identity papers is not so straightforward in practice and in law. While the state recognizes conversion to Islam from another religion, conversion from Islam to another religion is not officially recognized. While his public reversion to Islam in August is not covered extensively in Egyptian newspapers, echoes of the controversy sparked by his act of requesting legal recognition for conversion to Christianity continue to reverberate. In 2008, a court had dismissed his claim and ruled that Higāzì, born a Muslim, could not have his conversion recognized because this would amount to "apostasy" (irtida $\bar{d})$ and therefore contradict public order and morals. In a program aired during Ramadan, ${ }^{2}$ shaykh al-Azhar Ahmad al-Ṭayyib elaborates, defining the boundaries of Islam, that apostates should not be punished by death. As noted by the head of al-Azhar's Committee in an interview to al-Sabāh on April 12:

God acknowledges the freedom of humans to choose a religion or belief without coercion (...). Apostasy (ridda), however, is a major sin (min al-kaba $\vec{a} i r)$ as it signals disbelief in God and his Holy Book. ${ }^{3}$

This definition of Islam has the effect of authorizing intervention in the domain of belief [ $>$ Private $\boldsymbol{v s}$ Public; $\nearrow$ In Islam...]. Due to social stigma and legal obstacles associated with conversion from Islam to other religions, the number of individuals who seek official recognition of such conversions is very small. Some, such as Muhammad Higāzī, live in fear for their lives. Possibilities of tricking the system through forgery of ID documents exposes people to the risk of prosecution [ $>$ State $v$ s People, $>$ Tricking the system].

Journal of Arabic and Islamic Studies 17 (2017): 474-478

(C) Monika Lindbekk, Dept. of Culture Studies \& Oriental Languages (IKOS), University of Oslo / Norway 
But how to convert to Islam? In principle, it suffices to pronounce the shahāda. In practice, however, things are not so straightforward. An investigative article titled "Want to convert? Meet me later" offers an account of this process. ${ }^{4}$ The female journalist begins her adventure into the labyrinth of Egyptian bureaucracy by recounting how she enters the premises of al-Azhar. Mashyakhat al-Azhar is housed in a bulky concrete building located next to a busy intersection. Inside the building, she reaches an office on the ground floor carrying the sign "Announcement of Islam for Egyptians" (Iẓhār al-Islām li'l-Mișriyyīn). There she encounters five employees, four men and one woman, all in their early twenties, with a mandate to oversee the registration of converts to Islam. In this connection, they seek to ascertain whether potential converts indeed believe in God and his Prophet and freely consent to convert. According to the young employees, the following documents are required in support of changing one's religion:

1. A certificate of approval granted by the Mufti of Egypt to ensure his acceptance of her entrance into Islam, that she is not underage, and the presence of two Muslim witnesses

2. A written approval from the Ministry of Interior

When the author says that she has difficulties procuring the necessary documents (especially the validation from the Ministry of Interior), she is advised to pay a visit to al-Azhar's Fatwa committee which is situated to the right of the entrance to Azhar mosque. On the wall is a sign saying that pronouncement of fatwas is not conditioned by payment of a fee. In a Kafkaesque twist, an employee at al-Azhar's Fatwa Council gives her the address of a small mosque in the semi-rural area of Shubrā al-Khayma for the sake of speeding up conversion procedures. At the mosque she is welcomed by a husband and wife who volunteer to teach prospective converts about the rituals and obligations of Islam. The wife assures her that they receive no profit for doing this. The author of the article subsequently visits the couple at their home where she is initiated into the Islamic way of life, the characteristics of the Prophet and the angels, along with the ritual of prayer. The initiation ceremony takes place inside a small living room decorated with Quranic verses and is accompanied by low Quranic music playing on the radio. In the bestselling novel Fì qalbī unthà ibriyya (difficult to render, but tentatively "The Jewish Girl in my Soul") by the Tunisian author Khūla Hamdī. An episode of conversion is used to make the reader experience the true spirit of Islam. Situated against the backdrop of multi-confessional South-Lebanon, the book offers a glance at relations between Christians, Jews, and Muslims during moments of personal and political upheaval. In 1994 Ahmmad, a member of anti-Israeli resistance, gets injured during a military mission behind the border close to Qānā, South-Lebanon. Nadà, a Lebanese Jew, accommodates him and his companion and treats their wounds. Aḥmad and Nadà fall in love and subsequently Aḥmad proposes to Nadà and they get engaged despite the objection of Nadà's mother who is an orthodox Jew. During their engagement period, Nadà attempts to convert Aḥmad to Judaism, but instead develops an interest in Islam after Ahmmad argues for the rationality of his religion. Khūla Hamdī's book depicts different stages in the conversion process. These include opening oneself to new options; meeting a person who embodies the religious vision (Ahmad); finding a home (in Islam, depicted as a home for the homeless, likened to warm tea); and committing oneself to an Islamic way of life, embodied in Nadà's donning of the hijab [ $\nearrow$ In Islam...]. The process is compelling 
and transformative, but hardly smooth and seamless. Nadà is disowned by her orthodox Jewish mother due to her wearing the headscarf. Suffering on account of her conversion to Islam, Nadà is portrayed as a "martyr of true belief". While the novel on the surface seeks to advance a vision of religious tolerance, it is marked by power hierarchy. In line with the apologetic stance adopted by much literature on the Islamic way to self-help [ $\nearrow$ In Islam, $\nearrow$ Self-help], the novel is consistent in portraying Islam as superior compared to other religions, embodied in the adoption of Islamic identity and mode of dress by a young Jewish woman [ $\nearrow$ Superiority $v s$ Inferiority].

Khūla Hamdī's idealized portrayal of Islamic tolerance stands in contrast to the accounts of inter-religious conflict found in newspapers. The investigative journalist from alSabāh sheds further light on the dynamics of conversion when, on another day, she visits a Coptic church in Shubrā al-Khayma. She tells the security guard that she is a Muslim woman who wishes to change her religion to Christianity. After the sermon, she is granted a meeting with the priest after talking with the security guard. Patiently, the priest tells her that

Only God cares what stirs in people's hearts. You do not have to be a Christian on paper to be one of us. Our church is open to you in case wish to come here and worship. But I can't help you with more than that. [ $\nearrow$ Dual Identities / Masking]

The investigative journalist also tries her luck with the head of the Jewish community. After broaching the subject of her prospective conversion from Islam to Judaism, the journalist is met with the following reply: "You are going to bring about a disaster on me (inti ha-twaddinn fi dāhya)!" whereupon the phone is closed. The brusque response has to be seen against the background of the precarious status of the Jewish community in Egypt. Since the establishment of the state of Israel in 1948, many Egyptian Jews were expelled or compelled in other ways to leave the country. Once a thriving community, the Jews in Egypt have been reduced to six elderly women, reports Egypt Independent in July. ${ }^{5}$

While historically, conversions to Islam were welcomed, there are indications that they nowadays are increasingly deemed a threat to national security as they tend to be associated with sectarian tension and conflict [ 7 Security vs Fear]. On January 29, Nujüm mișriyya reports that the Țura prison administration had to separate Muslim Brotherhood supporters after they forced three Christian prisoners to convert. ${ }^{6}$ The stories that attract most media attention, however, revolve around female converts to Islam. On May 7, Ilā $f$ (Elaph) newspaper uses the term "secterian crisis" (azma țäifiyya) to describe a series of incidents in which Coptic girls in Upper Egypt have allegedly converted to Islam. In June, an eighteen-year-old Coptic girl disappears from a village in Upper Egypt after reportedly converting to Islam. In another village a rumour spreads that a Christian woman has eloped with a young man named "Islam". ${ }^{7}$ Demonstrations erupt outside the local police station where male members of the local Coptic community demand that the girl be returned to her family. On the other side, the local Muslim population accuses the police of colluding with the Coptic Church to prevent such conversions. Subsequently some men are arrested while others are dispersed. In response to these emotional demonstrations, the head of the local security directorate issues a statement that the woman in question is not held in police custody, but is on a train to Cairo to announce her conversion to Islam at al-Azhar. The eighteen-year-old girl appears in a videoclip on YouTube [ $\nearrow$ Social media]. ${ }^{8}$ The video shows 
her wearing a black hijab and giving a furtive smile while announcing her belief in Islam. Her declaration is less rehearsed than that of Muhammad Higāzī; in the background, the voice of a man can be heard reciting the shahāda, which she repeats after him. Shrouded in mystery, this episode, as others like it, gives ample room for speculation: did the woman in question convert willingly or was she in fact kidnapped and forced to adopt Islam? [ 7 True vs False] The fact that women's conversion elicits such anxiety can probably be explained by common assumptions about women's relations with men who are neither their husbands nor belong to their families and religious communities, particularly in the governorates of Upper Egypt. Expressing fear and anxiety over this and other similar incidents, some Copts try to create an association aimed at handling what they view as the growing phenomenon of forced disappearances and kidnapping, but they fail to obtain the official permit required [ $\nearrow$ Disappearances]. Returning to the article in $a l-S a b a \bar{h}$, an approval from the Ministry of Interior validating the conversion and change of name in ID card is noteworthy among the documents required for conversion to Islam. This signals that a closer monitoring of the boundaries between religious identities has come to be viewed as necessary step to prevent further sectarian tension and agonism, as reflected in a statement by the head of al-Azhar's Fatwa Committee:

According to God, the believer is free to believe and the disbeliever to disbelieve. However, in cases where conversion leads to fitna on account of social disapproval, the issue is referred to national security agencies and the judiciary for the sake of protecting the individual and nation. ${ }^{9}$

Conversions may put society at risk of fitna, "trial, temptation, sedition, civil strife"- the word reminds of the big schism in early Islamic history that led to the Sunni-Shia split and has become almost synonymous with civil war ever since. In light of this and other barriers facing converts attempting to change religious membership religion in ID cards, the author of the article wonders whether the principle of freedom of religion that is found in the 2014 constitution is not just "ink on paper" (hibr 'alà waraq), as the popular Egyptian proverb says [ $\nearrow$ Idea vs Practice].

\section{Related Entries}

Arrays: Disappearances; Dual Identities / Masking; In Islam...; Self-help; Social media; Tricking the system $\downarrow$ Codes: Idea $v s$ Practice; Private $v s$ Public; Security $v s$ Fear; State $v s$ People; Superiority vs Inferiority; True vs False

\section{References}

al-Buhayrī, Aḥmad, "Shaykh al-Azhar: Ḥurriyyat al-i'tiqād shay’ wa-ḥurriyyat al-irtidād shay” ākhar," al-Miṣrī al-Yawm, June 16, 2016, <http://www.almasryalyoum.com/news/details/965579> (accessed November 1, 2017).

al-Ṣabāḥ: “"Āwiz tighayyir diyāntak fì Maṣr, ibqà qābiln̄̄,” al-Ṣabāh, April 12, 2016, <http://www. elsaba7.com/NewsPrint.aspx?Id=142416> (accessed November 1, 2017).

‘Abd al-Hafị̄̄, Șabrī. “al-Aqbāt yataz̄āharūn li-sti'ādatihā wa'l-muslimūn li-tasallumihā,” İlāf, May 7, 2016, <http://elaph.com/Web/News/2016/5/1087240.html> (accessed November 1, 2017). 


\section{Monika Lindbekk}

'Abd al-Hamīd, Rīm, "Bi'l-fĩdiyō... Christian Today: șāḥib awwal dacwà qaḍā̄iyya li'l-taḥawwul li'lmasīhiyya ya'ūd li'l-Islam," al-Yawm al-Sābic, August 5, 2016, <http://www.youm7.com/ sto-

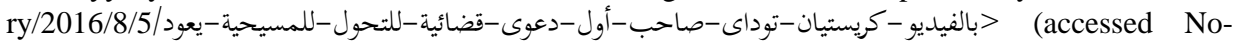
vember 1, 2017).

Egypt Independent: "Egypt's Jewish community diminished to 6 women after death of Lucy Saul," July 30, 2016, <http://www.egyptindependent.com/egypt-s-jewish-community-diminished-6women-after-death-lucy-saul/> (accessed December 15, 2017).

Nmisr: "Quwwāt al-amn ta`zil anșār al-ikhwān al-muslimīn ba'd tasabbubihim bi-islām thalāth masīhiyyīn

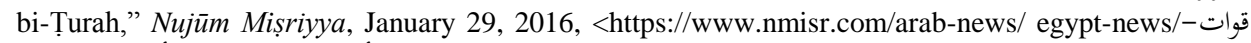
(accessed November 1, 2017).

(C) Monika Lindbekk,IKOS, University of Oslo / Norway 4 monika.lindbekk@ikos.uio.no 


\section{Crowdfunding}

Meet Rabiha and Hiba, two women artisans working with Aatik who together wove this carpet. They, along with six other women, want to keep working together-and they need your help in order to become a self-sustainable cooperative. Thus, for everyone abroad who hasn't donated yet, please visit the page: 〈link〉. For everyone in Tunisia who cannot contribute online, please ask your family and friends abroad to contribute to Aatik's crowdfunding campaign or contact Aatik's team and we will help you make a donation. Hurry, beautiful people, there are only 2 days left to \#weavearevolution!

Emma and Sophie, founders of the Tunisian start-up company Aatik, share this post on Facebook in mid-December 2016 [ $/$ Social Media]. Their objective is to keep alive the weaving tradition of the village of al-'Arūsa, a few hours from Tunis, by establishing a workshop managed exclusively by women. For this, they ask people living abroad and in Tunisia, to donate a small sum of money. The post includes a picture of Rabiha and Hiba proudly holding a blue-coloured carpet and showing their thumbs up, in a sign of confidence. And in fact, only one week later, they announce in another Facebook post: "We did it! We obtained $111 \%$ of the planned budget (3450 Euros). We are ready for a new year endowed with weaving, creativity and women power."

The campaign launched by the women behind Aatik is not an isolated case. A significant number of artisans, musicians, writers, social workers and young entrepreneurs from Egypt and Tunisia resort to crowdfunding to realize their professional dreams [ $>$ Young vs Settled]. They have great ambitions and creative ideas; the main obstacle they face is access to funding, particularly when firms are at an early stage. Banks simply do not want to take the risk. Administrative steps for review and approval take a lot of time and are often discouraging. Crowdfunding websites, instead, are easy to access [ $\nearrow$ Tricking the system]. They allow anyone to create a page where they describe the idea of a project, give an estimated budget and schedule for its realization, and ask friends, family, like-minded people and other potential investors to contribute by donating a small amount of money within a fixed deadline. Not only international crowdfunding websites, like Kickstarter or Indiegogo, which world-renowned artists like the Tunisian singer Emel Mathlouthy (Āmāl alMathlūthī) [ $\nearrow$ Celebrities] resort to, are used; but increasingly also Arabic crowdfunding websites appear, and they aim at financing local projects, like zoomal (DhūMāl "The one who has money"), CoFundy or AfrikWity, whose offices are in Tunis, or Yomken (Yumkin "It is possible"), and Shekra (from Shärik fikra "Share an idea"), based in Egypt.

Different websites have different policies. But usually, if the project is successfully funded, the website keeps a small percentage of the total money donated (5\% for zoomal, or $10 \%$ for Yomken, for example). If the planned amount is not reached within the given time, the website may adopt two funding options: "all or nothing" (like zoomal), or "keep it all." In the former, pledged money is only collected if the fundraising goal is met, other- 
wise the money is returned to the backers. In the latter, the funds are collected whether the project goal is met or not.

In exchange for their support, backers can be rewarded in several ways, depending on the sum of money allocated. For example, the ones who "support a Room of art in Cairo"- - a music venue that risks being shut down due to the financial crisis in Egypt [ $>$ Dollar Crisis] - will obtain honorary membership access to the venue, discounts on concert tickets and beverages, and a photo on stage with a music band performing there. The ones who support the establishment of a canteen for a primary school located on the Islands of Qarqna (Kerkennah) in Tunisia will get a boat tour of the island, a meal served in the canteen with the school pupils, and their name and picture recorded in the school annals. But more in general, donors are rewarded with the feeling that they can determine which project will be realized, and thus make a difference [ $\boldsymbol{\gamma}$ Freedom $\boldsymbol{v} \boldsymbol{s}$ Constraint, $\nearrow$ Individual vs Collective]. Emel Mathlouthy uses these words to ask her supporters to help her produce her new album:

If you believe that a woman can be an independent creative and a free artist, please help. If you believe that labels aren't the only ones who should decide what has artistic value, and what you listen to, please come along on this journey... Music is in danger of being silenced.

While the campaign takes place online, the projects advertised on these websites are often conceived and launched in the new cafés [ $\nearrow$ New cafés] or in trendy co-working spaces situated in Cairo and Tunis. For example, Aatik was envisioned at Co-gite, a shared working environment which consists of a deluxe villa equipped with a swimming pool and garden, located in the posh area of Le Lac in Tunis [ $>$ Gated communities/Compounds]. The place is managed by a Tunisian businessman who wants to offer young Tunisian entrepreneurs the possibility of brainstorming, as well as taking a nap or watching a movie together, on the model of American start-up companies. In Cairo, some of these co-working spaces consist of big flats where young entrepreneurs may work shoulder to shoulder with a translator or a graphic designer.

Thanks to crowdfunding, a number of projects in Egypt and Tunisia actually do get financed, among them a dystopic play entitled First Draft, set between a static present and a future marked by an environmental catastrophe [ $>$ Hope = Despair / Hell (Dystopia)]; a two-week summer camp gathering more than sixty youngsters from Arab countries on a journey of learning and self-expression [ $\not$ Self-help]; the production of hundred videos on marriage, pregnancy, childbirth, parenting, health and more in both English and Arabic, accessible for free on the Internet [ $>$ Baby milk]; the establishment of a Tunisian company named Audiolaby that produces free and paid audiobooks, podcasts and audio stories for children; a project for print on demand allowing emerging authors to decide the number and format of the books they want to publish without having to deal with commercial publishing companies; a movie on high-speed car accidents in Egypt; the restoration of the Rashīdĩ Institute for Tunisian Music (originally established in Tunis in 1924), with the aim of devoting part of the building to a co-working space and turning its physical library into a digital open access archive. Among the projects that do not make it: the creation of a 3D Tunisian TV comedy, and an e-commerce site for Egyptian textiles. 
Crowdfunding is widespread, but it faces several challenges, the biggest being that ecommerce is not fully established in the Arab world. Many Tunisian and Egyptian citizens do not have access to a credit card in their home country, so fundraisers need to rely mainly on their fellow countrymen living abroad [ $\nearrow$ Migration]. Inside the country, however, one can also use money transfer agencies, like Western Union, or organize group meet-ups. The women of Aatik, for instance, hold a number of roundtable discussions in December at Cogito, where they illustrate their project and invite their "followers" to donate to the project. The Room in Cairo publishes a video on their Facebook page to invite people to visit their venue and register as members to the association.

\section{Related Entries}

Arrays: Celebrities; Dollar crisis; Music; New Cafés; Social Media; Tricking the System • Codes: Individual(ity) vs Community/Collectiv(e/ity); Young vs Settled; "The System" vs "the People" $\downarrow$ Codes collapsed: Normality = Heroism (Surviving); Hope = Despair / Hell (Dystopia)

\section{References}

Aatik, "Meet Rabiha and Hiba, two women artisans working with Aatik who together wove this carpet", Facebook Status Update, 13 December 2016, <https://www.facebook.com/aatik.project/ ?hc_ref=ARQFjgW3UDv9aWDMJWWI2Hh2rdQDw7a11-vfoSSOS7cb9ZBajWnbtk4RGDLExx MG5GM\&fref=nf $>$.

Aatik, "Friends of Aatik! C'est le grand jour de la table ronde et votre chance de soutenir les femmes artisanes de 1'Aroussa," Facebook Status Update, 9 December 2016, <https://www.facebook.com/ aatik.project/?hc_ref=ARSC1bf011aG-c3h_Pva6he7euXHaOVRM1kNjxorYgnCHcOTyr8o8ED oUVJ8ZXezgcs\&fref=nf>

Arab Crowdfunding, 〈http://www.arabcrowdfunding.com>.

Cofundy: Plateforme de Crowdfunding en Dons Pour l'Afrique, <www.cofundy.com>.

"Crowdfunding Campaign to Revive the Art of Egyptian Quilts", Cairo Scene, 17 June 2016, <http:// www.cairoscene.com/LifeStyle/Crowdfunding-Campaign-Aims-to-Revive-the-Art-of-EgyptianQuilt>.

Indiegogo: Crowdfund Innovations \& Buy Unique Products, <www.indiegogo.com>.

Lilia, Blaise, and Sbouai Sana, "Revolution Has Allowed Young Tunisian Entrepreneurs to Dream Big," True Africa, 19 August 2016, <https://trueafrica.co/article/co-working-spaces-in-tunisia/>.

The Room, “رووم محتاج دعمكم و مساندتكم Room needs your support", Facebook Video, 7 December 2016, <https://www.facebook.com/roomartspace/videos/1206535712762168/>.

Zoomal: Crowdfunding Platform of the Arab World, <www.zoomal.com>. 


\section{Dérja}

In 2016, Tunisian TV stations for the first time in their history begin to dub Turkish soap operas in Tunisian (i.e., the Arabic variety spoken in Tunisia). Until then, in Tunisia Turkish films used to be broadcast with translations in Lebanese or Syrian Arabic. The first dubbing attempt is made in the TV series Qlüb er-Rommān ("The Pomegranate Seeds"), a melodramatic story about an unmarried lower-class surrogate mother who falls in love with the main hero, the father of the child she is hired to carry to term [ $\nearrow$ Affluence vs Destitution], with typical soap-opera ingredients, like jealousy, rivalry among women, and vengeance.

The choice of Tunisian is initially perceived negatively by some in the audience, but appreciated thereafter. The series is broadcast on the private television channel Nessma $T V$. Like other television and radio channels, Nessma $T V$ relies on the use of the Tunisian language, even in its news broadcast.

Several social events mark the spread of Tunisian in the public sphere through different media. Azyz Amami, a cyberactivist in his early thirties who had participated in several demonstrations before the Revolution, now commits to support the diffusion of $\mathrm{Tu}$ nisian by translating philosophical and literary classics (Gramsci, Barthes, Plato, etc.) into Tunisian [ $\nearrow^{C} \overline{\mathbf{A}} \mathbf{m m i y y a}$ ]. Writing in Tunisian on social networks is also thriving [ $\nearrow$ Social media]. In addition, the newspaper Medina starts to publish in Tunisian to better represent the medina of Tunis where its head office is located. The association DERJA obtains an authorisation to start its activities and promotes recognition of Tunisian as official language through a process of standardisation and normalisation.

Annava, a music band who define themselves as a "group of young Tunisians", releases a song titled "Zaboubia" (zabūbiyya). Its lyrics correspond to a poem written in Tunisian by 'Abd al-Raḥmān al-Kāfī, a communist poet who died in the early 1930s. The word he created, zabübiyya, comes from the term $e z-z e b b$, an 'indecent, improper' word that literally means "penis" and can be used as an insult. The poem critiques all kinds of authoritarianism in Tunisian society-in politics, academia, and religion [ $\nearrow$ Satire; $\nearrow$ Culture vs Politics].

Due to lack of official recognition and absence from school curricula, the dérja is often placed in a marginal or at least ambivalent position.

\section{Related Entries}

Arrays: 'Āmmiyya; Social media; Satire • Codes: Affluence vs Destitution; Culture vs Politics. 


\section{References}

http://www.jomhouria.com/art46063_هذا ما كشفته قناة نسمة بخصوص المسلسل التركي باللهجة التونسية, January 17, 2016.

http://www.bettounsi.com/

https://issuu.com/journaldelamedina

https://www.azyzamami.tn/members/azyz/

https://www.facebook.com/annavaband/

(C) Myriam Achour Kallel, Université de Tunis / Tunisia Mariem Guellouz, Université Paris Descartes / France $\checkmark$ mguellouz@yahoo.fr | myriamkallel@yahoo.fr $\downarrow$ 


\section{Dual identities / Masking}

Traditional roles and identities are being challenged in 2016, or threatened. Accordingly, much of the year's cultural production features protagonists who (have to) play several roles at one time, or live double lives, and/or are torn between conflicting identities.

This may be due to pure economic necessity which forces the poor into taking multiple jobs [ $\nearrow$ Dollar crisis/azmah]. Many documentaries, as well as fictional representations, focus particularly on women who are struggling to earn a living for themselves and their families. In doing so, they take over many traditionally male responsibilities [ $\nearrow$ Male $\boldsymbol{v s}$ Female]. In the Tunisian documentary Les commerçantes and the Egyptian movie Nawwāra, such women are the wives of husbands who cannot find a job or earn too little for the family to survive; in the Egyptian documentary Abadan lam nakun atfālan ("We Have Never Been Kids"), the woman portrayed (Nādiya) has separated from her former husband because he had always beaten her and spent all his money on drugs. Nawwāra and Nādiya both live in slum quarters [ $\nearrow^{c} \boldsymbol{a s h} \boldsymbol{w} \overline{\boldsymbol{a}} \boldsymbol{i} \boldsymbol{i} y \boldsymbol{y} \overline{\boldsymbol{a}}$ ], while the Tunisian women are lower middle class from the South [ $\nearrow$ Center vs Periphery]. All of them do their utmost to fulfil their double roles as mothers and housewives on the one hand and as working women, and sometimes family heads, on the other. While Nawwāra is so lucky to have found a job as a housemaid with a rich family in one of New Cairo's gated communities [ $\nearrow$ Gated communities, $\nearrow$ Affluence $v$ s Destitution], Nādiya toils as a knife and scissors grinder, a profession she learned from her father. But she does not earn enough to spare her children the duty of assisting her by taking odd jobs to make ends meet, a fact that forces also the children into double lives: they cannot be just children, but also have to contribute to the family's income by working as drummers in wedding bands, casual workers at building places, or parking attendants (sāyis) (as Nādiya's eldest son, Khalīl), kitchen hands in kosharī restaurants or $t u k$-tuk drivers (as her other son, Nūr) [ $\nearrow$ Tuk-tuk], or by having to marry at the early age of fifteen (as her daughter). However, although their jobs give Nādiya and Nawwāra roles and positions that resemble traditionally 'male' roles and positions, the women are neither particularly fond, nor proud, of their 'emancipation'-for them, working outside the house is simply an economic imperative. In contrast, the Tunisian tradeswomen we meet in Les commerçantes seem to experience their 'second lives' not only as dictated by necessity, but also as an opportunity and an enrichment. The success of their enterprises - a result of their inventiveness and creativity [ $\boldsymbol{i} \mathbf{i b t i k} \overline{\boldsymbol{a}} \boldsymbol{r}$ ] — has given them courage and self-confidence and a more positive outlook on life, mirrored not only in their colourful dresses but also in the merry atmosphere on the little van that takes them to their working place. To have two jobs and lead two lives demands a lot of energy, yes; but it is also rewarding: you develop qualities and aspects of your self that otherwise would have remained hidden, and you gain the freedom to actually live this self.

In this, the lower middle class commerçantes from the Tunisian south are not much different from the shabāb, portrayed in al-Hufra ("The Pit"), who are theatre enthusiasts and dream of being able, one day, to create a play of their own. However, before this may be- 
come possible - if at all - they have to master the challenges of everyday life in a poor Tunisian village and to meet the expectations their families placed in them. Yet, what they can do already now is to try to combine, at least partly, business with self-fulfilment: dressing as clowns or jugglers and performing entertaining sketches on the street, or acting as Kitty dancers on children's birthdays, or giving puppet plays, they can earn some money and at the same time 'become themselves', become actors.

Interestingly enough, it is also only in disguise, behind the mask of such costumes, that they dare to express themselves freely and comprehensively: "In pantomime, we play [ultimately] what we are, our own experiences, our lives, our suffering." The mask of a fictional identity provides also others with the precious protection they obviously need to dare to 'be themselves'. The existential crisis experienced by Khālid, the protagonist of $\bar{A} k h i r$ ayyām al-madina ("The Last Days of the City"), is without doubt to a large extent the author's, Tāmir al-Sa'̄ìd's, own crisis, a crisis that also paralyzes his creativity; but instead of assessing it with the help of an autobiographical documentary, al-Sa '̄id creates "Khālid", an alter ego, an 'avatar'. Feeling alienated and homeless, like "tramps", mutasharridinn—so called in Șawt al-shāri ("The Voice of the Street") / Cloch'Art and Nihāyāt sa'īda ("Happily Ever After")—, not knowing in which direction you should go [ $>$ Stuck], makes you feel weak and vulnerable; in contrast, the mask of fiction empowers and protects you, provides immunity: the alter ego is you, but it is also not you, it is somebody else. The whole genre of dystopian fiction that continues to flourish in 2016-a prominent representative, Muhammad Rabī's 'Uțārid ("Mercury"), even gets shortlisted for the International Prize of Arabic Fiction-profits from this function of fiction: behind the mask of an imagined future, the present situation can be powerfully criticized [ $>$ Dystopia] while the authors cannot be accused of attacking the regime or portraying the current state of affairs directly or too shamelessly. In many satirical YouTube channels, too, the YouTubers put on a 'mask' when they choose to appear as serious news presenters, scientific consultants, or talk show masters, or when they let cartoon characters or muppets play 'typical' roles, from the policeman to the jealous fiancée, from the poor witty shābb to the President himself; in 'Ali Mi za wa-Ibrāhim ("Ali, the Goat, and Ibrahim"), a key role is played even by a goat! It seems to make good sense that the English word mask and the Arabic word for 'satire', sukhriyyah, perhaps are etymologically related. ${ }^{1}$ However, to take on another identity also allows you to imagine, if only for a short time, a happier reality: In Hārr jâff șayfan ("Dry Hot Summers"), the old gentleman Shawqī, suffering from incurable cancer, can pose for a few moments in the role of the bridegroom of young pretty $\mathrm{Du}^{\mathrm{c}} \overrightarrow{\mathrm{a}}$,vibrantwithlife;we know that this is only ephemeral-Shawqī's face will soon be replaced, thanks to Adobe Photoshop, by that of the true bridegroom, who just couldn't make it in time to the photo

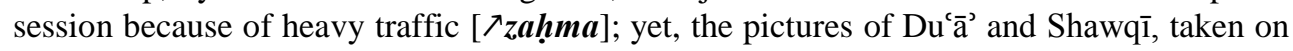
this occasion, imagine the gaps of a fragmented society as bridgeable, all differences, even that of life and death, as reconcilable - a short moment of humanity and happiness in an else all too hectic, inhumane present, full of constraints that force too many roles upon everybody and make it almost impossible to change one's life and identity [ $\nearrow$ Freedom $\boldsymbol{v s}$ Constraint]. Another fantastic vision comes with the short movie Qindīl al-baḥr / Kindil ("The Jellyfish") in which a young woman, after being harassed and killed by a group of men, metamorphoses into a terrible medusa who takes revenge on a society that made it possible for such a crime to be committed against her. Although an Algerian production, it 
makes use of a technique that is very similar to forms of 'masking', described above, that also Egyptians and Tunisians often have recourse to, and it also applies it to a similarly sensitive topic that continues to be a hot issue in Egypt as well as Tunisia [ 7 Male $\boldsymbol{v s} \mathbf{F e}$ male].

Not future visions but representations of a deplorable present reality are the hidden identities and/or double lives that we meet in a number of productions dealing with marginalized, oppressed, or threatened social groups, mostly minorities. Christians and LGBT are the most obvious cases in point. In Ishtibāk ("Clash"), a nurse hurries to cover the cross tatoo that identifies the man she treats as a Copt - the atmosphere in the packed police van into which they have been forced together with many others and which symbolizes society in a nutshell, is loaded with tension to such a degree that she fears that the situation might explode, and the Copt's life be in danger, if the religious fanatics with whom they have to share this tight space would learn of their fellow citizen's Christian identity [ $>$ Clash]. In Mawlānā ("Our Master" / "The Preacher"), the unorthodox, freeminded imam Hâtim is approached by a rich and influential contractor who is close to the inner circle around the President: his wife's brother Husayn has converted to Christianity, an incident that is classified as top "military secret". Scandal is imminent, and a state affair may erupt if it should become known that Husayn not only is an apostate but also has withdrawn considerable amounts of - public — money and donated it to the Coptic Church; Husayn's conversion and adoption of the Christian name "Butrus", and thus his new identity, have to be concealed from the public [ $\nearrow$ Conversions].

The fact that gay and lesbian people still have to conceal their sexual orientation and are unable to live their true identities in the open but have to resort to a parallel, secret, hidden second life as the only way to 'be themselves', is shown, and in most cases also implicitly criticized, in not a few productions, both documentary and fictional. In the documentary Travesties, Tunisian transvestites from Gabès travel to Sousse, and it is only there, masked not only in their cross-dresses but also protected by the 'mask' of anonymity as foreigners, that they can really begin to live. No wonder that after longer periods of suppression, their true identity virtually explodes: their dancing in a club takes on almost ecstatic traits [/Dancing / Music]. Yet, compared to little Nūr whom we meet in Abadan lam nakun atfälan, they still appear almost privileged. Growing up in a slum as the second son of single mother Nādiya (whom met above), Nūr never gets the chance to be just a kid; from an early age, he has to earn money to contribute to the family's income, and he ends up doing this as a child prostitute. In this way he becomes a homosexual himself-which makes life even more difficult for him, given the persistence of society's discrimination of homosexuality as 'abnormal' (shädhdh). The psychological pressure upon him becomes all the more difficult to bear as Nādiya and his elder brother, Khalīl, condemn his leanings, Khalīl being beside himself with rage because he thinks Nūr is dragging his and the family's honour through the mud. At the end of the documentary, the boy has disappeared, with nobody knowing anything about his whereabouts [ $>$ Disappearances]. As for Khalīl, he tells the film director on the phone that he, too, is leaving now - to join the IS forces-because he has come to a point where "I either have to die myself or kill others".

Like Khalīl, many adolescent men take this step, deciding to become another and leave their old identities behind to start new lives - as true Muslims. Very often, their motivation is similar to Khalīl's, even if their families' situation is less precarious. 17-year-old Murād

jais • 17 (2017): 484-491 
in Zahrat Halab ("The Flower of Aleppo"), for instance, is the son of a middle-class couple who have separated; he despises, and is ashamed of, his "lousy father" who is a "lazy artist", a looser, an intellectual, and a drinker, unable, like his mother, to give the boy/young man the orientation he needs; therefore Murād is easily attracted by salafist ideology and ends up as a jihadist fighter in Syria [ $\nearrow$ Disappearances] — as thousands of others like him. (The issue has already been dealt with for some years now, for example in the documentary Comdamné à l'espoir of 2014, but has lost nothing of its actuality, which is why it is chosen as one of the top five Tunisian documentary shorts to be shown on Arabic film festivals in 2016). Not the parents' separation or divorce, but the experience of having been raped by a brutal policeman during the Revolution [ 7 The Policeman criminal] is the traumatic experience that turns Husayn in Ghadwa hayy / Demain dès l'aube ("Burning Hope"), about the same age as Khalīl and Murād, into a terrorist. Far away from the Tunisian capital, he tries to forget the humiliation he has suffered, but he cannot. Thus, his mother-like so many other mothers, fathers, friends, in other productions - notices that the boy withdraws from this world, observes him changing, becoming calm and shy, not relating to his familiar surroundings any longer. In all these films, the mutation of the disoriented youth from sensitive boys to desperate killers or suicide bombers is shown as a slow process of transition from one identity to another, with the characters for some time leading two parallel lives. Trauma treatment would perhaps have helped them to come to terms with what they have gone through [ $>$ Psychiatrists]. But they are too ashamed of their weakness in a society that expects them to be strong, not "like women" [ $\nearrow$ Superiority vs Inferiority / Emasculation, $\nearrow$ Male vs Female].

In many respects, however, the reasons why also other youth are living double lives are quite similar to those of the Christians, LGBT, and the traumatized. Most of these others are rebels - against a patriarchal social and political order that they experience as repressive. At a certain point in their lives, they become dropouts, though very often continuing to keep appearances. In Sawt al-shāric/Cloch'Art, only the mother of one of the rappers portrayed knows that her son has a second identity as a singer of politically critical street music; they have to fear the police, so father better does not know [ Father figures]. Old men in a café to whom the group gives a demonstration of their music find it "un-Arabic" — as if the youth were betraying Arab identity (which, according to the old men, is epitomised only by Umm Kulthūm or 'Abd al-Wahhāb) [ $>$ Past vs Present, $\nearrow$ Youth vs Settled]. The wish to avoid conflict with the family and/or the political regime has been the reason also for the protagonists of Yallah! Underground and 'Alà hallat 'aynī / À peine j'ouvre les yeux ("As I Open My Eyes"), both produced already in 2015 but shown on film festivals in 2016 as still 'valid' representations of current realities. In her one life, 18-year-old Farah, the heroine of 'Alà hallat ' $a y n \bar{l}$, is a high school student whose application for medical school has just been accepted. In her second life, she is a highly gifted interpreter of daring, politically and socially critical lyrics - out of a desire, as the young director puts it in an interview, "to live life to the full" [ $\nearrow$ Self-fulfilment], a desire that is opposed to "family pressure and an omnipresent police state." ${ }^{2}$ Farah's wishes, her desires and passions, the whole of her personality clashes with what is presented as an essentially anti-human system of norms, taboos, and authoritarian claims to power that prevents her from unfolding her personali- 
ty, her identity [ $\nearrow$ Freedom vs Constraint, $\nearrow$ Individual $v \boldsymbol{s}$ Collectivity]. She can live her self only in secret, in her second life, behind the mask of her first life.

It is dangerous to be yourself. When the authorities become aware of Farah's oppositional activities she is detained and tortured. This is also what the rappers of Cloch'Art are afraid of, while Christians and LGBT mainly (though not only, cf. $>$ Conversions) fear Islamist aggression and the influence of self-appointed guardians of public morals on the people [ $\nearrow$ In Islam..., $\nearrow$ The HonourablelNoble citizen / al-Muwāțin al-sharīf]. Shame and fear of society's contempt or ridicule keep the traumatized and weak from coming out with their traumata and their weakness, while at least some of those who suffer from existential crises or creative 'impotence' seek protection under the mask of fiction.

Yet others seek refuge in emigration and try to build a new second life for themselves abroad, often in the West [ $\nearrow$ Emigration]. But there they either face the problem of how to remain themselves while having to adapt to a foreign culture and integrate into a foreign society (Zaynab takrah al-thalj / "Zeineb Hates the Snow"). Or the past they wished to get rid of, or at least forget, catches up and powerfully returns on them. Thus, although Sāmiya in Corps étranger, after an adventurous flight, has somehow 'made it' to France and begun to find out how to survive in Lyon as a "sans papiers", a refugee without papers, she receives mysterious phone calls, meets a young man who knew her brother, re-establishes contact with her mother in Tunisia, etc.- - and whatever she does, she still feels as if living in a foreign body (as the title has it): the 'mask' of her new (non-)identity can hardly prevent the specters of her former life from reappearing and breaking through.

Even though knowledge about problems of this kind is quite common - it was already in 2009 that Khālid al-Khamīsī organized his novel Safinat Nūḥ ("Noah's Ark") as a survey of migrant trajectories - emigration is nevertheless, and in spite of all odds, still often imagined as a viable solution not only by the many political and economic refugees who keep trying to reach the West, but also by those who probably might survive, somehow, at home without emigrating but who are unwilling to sacrifice their best years to a society they no longer can relate to. But the decision to leave one's former life behind also needs courage and the readiness to make a big effort — qualities none of which the protagonist of Nhibbik, Hād̄ / Hédi ("I Love You, Hedi") possesses. Deep inside himself, the 25-year-old Tunisian has already dropped out: neither his job nor the traditions, ideals and values held up by his parents provide him any more with a feeling of belonging or a meaning in life [ $\nearrow$ Alienation/ghurba]. But although he is well aware of this, and even though he actually gets a concrete chance to begin a new life-together with beautiful, self-confident, independent Rìm (the name means 'gazelle', associated with freedom in the Arabic tradition), whom he has fallen in love with and with whom he has experienced freedom and his true self - in the end, he does not show up at the airport where the two had agreed to meet to leave the country for good. He decides to stay behind, and with this gives preference to what seems to be safer and easier, less risky, notwithstanding that this means that he will fall back into his former double life: he will follow tradition and marry Khadija, ${ }^{3}$ the girl his parents have selected for him (and whom he neither loves nor has kissed once), and keep working in a boring job, while he will without doubt still dream of Rìm (who truly loved him and with whom he had fulfilling sex). Behind the mask of the established, average, 'arrived' married middle-class employee, Hādī will probably go on to live a second life, allowing him to "be himself" only in secret, perhaps for some days in the year at a

jais • 17 (2017): 484-491 
remote place where nobody knows him, like the tourist resort where he has met Rìm. - Reenacting the old plot of a young man torn between two women, one representing tradition, the other freedom, naturalness and authenticity, the movie presents the powerful parable of a nation at the crossroads, tending to persist in dated patterns while it would with all likelihood benefit from a more courageous approach that dares to take the risk of making steps beyond the paved ways of well-tried Tradition.

As the example of Hādī makes clear, the 'mask' of a double identity not only protects those who wear it, it also can do wrong or harm others, and it may also cover a feeling of guilt. The conditions Hādī lives in certainly are difficult, so he actually is a victim. However, out of weakness and love of comfort and security, he betrays not only himself but also Rìm, and he is dishonest against his parents and his fiancée. Corps étranger and Ghadwa hayy explore the same ambiguity: the protagonists are not only innocent victims there, but also offenders who have done wrong. In Corps étranger, it turns out that Sāmiya had a good reason to flee to France: her brother, who had become an Islamist, had started to impose on her his vision of how girls should behave according to the sharia [ $\nearrow$ In Islam...]. But did she have the right to indicate his whereabouts to the police? Her treachery may have been the reason for his sudden disappearance and incarceration, and later, torture and death. The three protagonists of Ghadwa hayy, too, have become guilty in the past: During the days of the Revolution, they had suffered violence and injustice from the police; however, when Zaynab saved Husayn from the claws of a policeman who was raping him she used an iron bar and beat the man extremely heavily; Husayn, infuriated, continued on him, kicked him half-dead; and neither he nor Zaynab nor Elyssa tried to help the wounded man but fled in panic. The policeman survived, but only with severe physical and mental handicaps: he will be a cripple, dependent on aid for the rest of his life. Here, as in Corps étranger, the whole story is revealed only gradually, in pieces, after the three revolutionary youth had put on their 'masks' and begun to build new 'post-event' identities for themselves. Five years after the revolution, however, the past returns on them, 'unmasking' them and forcing them to come to terms with the tragic truth: violence had created counterviolence and turned innocent victims into guilty offenders [ $\nearrow$ Innocence $v \boldsymbol{s}$ Guilt].

However, time seems ripe not only for such re-assessments. In many cases, the use of masks and hiding in new identities is less ambiguous, the fact of their actual abuse uncontroversial. Thus, al-Salāt wa'l-ma'raka / La Vallée du Sel ("Prayer and Battle" / "The Valley of Salt"), a documentary that portrays the life of a Coptic couple who receive death threats from religious fanatics - apparently some shabāb from the neighbourhood who call with suppressed caller IDs-leaves little doubt that it is the anonymous callers who commit a crime; the Christians themselves are completely innocent. Football hooligans, too, wearing the notorious Guy Fawkes masks, are mostly seen as mere offenders, and so are the police who put on cruel-looking, terrifying masks not only as a weapon to threaten the people, but also to be able, behind the mask of anonymity, to commit crimes against them [ $\nearrow$ The Policeman criminal]. It is this masking that inspired Muhammad Rabī ${ }^{-}$to make it a characteristic feature of life in Egypt in his dystopian vision of the near future. It is quite significant that his novel "Uțārid ("Mercury"), in which horrible crimes are committed by snipers wearing masks and where, moreover, masks have begun to replace the human face in general, is shortlisted for the International Prize of Arabic Fiction in 2016 as a powerful comment on the present. In many respects, 'masking' also seems to be an apt metaphor for 
what those in power are doing all the time: they disguise their true, criminal identities with the help of an official discourse of benign benefaction and working for the benefit of the nation [ $\nearrow$ True $v s$ False; $\nearrow$ Father figures; $\nearrow$ The voice from above]. But there are myriad initiatives that make it their task to reveal the 'truth behind' [ $\nearrow$ Social media, $\nearrow$ Satire]. Moreover, a number of movies stage the mechanisms of hiding as well as the processes of revealing. In both Mawlānā and the Nile Hilton Incident, for example, the circles close to the Egyptian President are shown to commit crimes, systematically suppress the truth and fabricate fake versions, while those who investigate and disclose and in this way play the roles of detectives are the films' indisputable heroes.

\section{Related Entries}

Arrays: Alienation/ghurba; 'ashwä̉iyyāt; Clash; Conversions; Dancing / Music; Disappearances; Dollar crisis/azmah; Emigration; Father figures; Gated communities; In Islam...; The Policeman criminal; Psychiatrists; Satire; Self-fulfilment; Social media; TukTuk; The Voice from above; zaḥma $\downarrow$ Codes: Affluence vs Destitution; Center vs Periphery; Freedom vs Constraint; Individual vs Collectivity; Innocence vs Guilt; Male vs Female; Past vs Present; Superiority vs Inferiority [Emasculation]; True vs False $\bullet$ Codes collapsed: Dystopia; ibtikār; Stuck

\section{References}

Cinema

Abadan lam nakun atfālan (We Have Never Been Kids). Documentary by Maḥmūd Sulaymān (Mahmood Soliman). Egypt, U.A.E., Qatar, Lebanon 2016.

Ākhir ayyām al-madīna (In the Last Days of the City). By Tāmir al-Sa'īd (Tamer el Said). Egypt, Germany, UK, U.A.E. 2016.

'Alà hallat 'aynī / À peine j'ouvre les yeux (As I Open My Eyes). By Leyla Bouzid. Tunisia, France, Belgium 2015.

'Alī Míza wa-Ibrāhīm (Ali, the Goat, and Ibrahim). By Sharīf al-Bandarī (Sherif El Bendary). Egypt, France 2016.

Les commerçantes (The Tradeswomen). Short film by Noussaiba Msallem. Tunisia 2015.

Condamné à l'espoir (Doomed to Hope). Short film by Youssef Ben Ammar. Tunisia 2014.

Corps étranger (Foreign Body). By Raja Amari. Tunisia, France 2016.

Ghadwa hayy / Demain dès l'aube (Burning Hope). By Luṭî Āshūr (Lotfi Achour). Tunisia 2016.

Hārr jāff șayfan (Dry Hot Summers). Short film by Sharīf al-Bandarī (Sherif Elbendary). Egypt, Germany 2015.

al-Hufra / La fosse) (The Pitch). Short film by Ashraf Hammāmī (Achref Hammami). Tunisia 2016.

Ishtibāk (Clash). By Muḥammad Diyāb (Mohamed Diab). Egypt, Germany, France 2016.

Jeanne d'Arc Masriya / Egyptian Jeanne d'Arc. Documentary by Īmān Kāmil (Iman Kamel). Egypt, Germany, Kuwait, Qatar 2016.

Mawlānā (Our Master) / The Preacher. By Magdī Aḥmad 'Alī (Magdy Ahmed Ali). Egypten, U.A.E. 2016.

Nawwāra (Nawara). By Hāla Khalīl (Hala Khalil). Egypt 2016.

jais • 17 (2017): 484-491 
Nḥibbik, Hādī / Hédi (Hedi). By Muḥammad Bin 'Ațiyya (Mohamed Ben Attia). Tunisia, Belgium, France 2016.

Nihāyāt sa īda (Happily Ever After). Documentary by Nadà Riyāọ (Nadà Riyadh) and Ayman alAmīr (Ayman El Amir). Egypt 2016.

The Nile Hilton Incident. By Țāriq Șāliḥ (Tarik Saleh). Egypt, Germany, Sweden, Denmark 2017.

Qindīl al-bahr (Kindil). Short film by Damien Ounouri. Algeria, France 2016.

al-Salāt wa'l-ma'raka / La Vallée du Sel (Prayer and Battle / The Valley of Salt). Documentary by Christophe Majdī Șābir (Magdy Saber). Egypt, Switzerland 2016.

Sawt al-shāric (The Voice of the Street) / Cloch'Art. Documentary by Manāl Qațīi (Manel Katri). Tunisia 2016.

Travesties. Short film by Safoin Ben Abdelali. Tunisia 2015.

Yallah! Underground. Documentary by Farid Eslam. Egypt, Czechia, Germany, UK, Canada, USA 2015.

Zahrat Halab (The Flower of Aleppo). By Riḍà Bāhī (Ridha Behi). Tunisia 2016.

Zaynab takrah al-thalj / Zaineb n'aime pas la neige (Zeineb Hates the Snow). Documentary by Kawthar Bin Haniyya (Kaouther Ben Hania). Tunis, France, Qatar, Lebanon, U.A.E. 2016.

Novels

Khālid al-Khamīsī. 2009. Safinat Nūḥ (Noah’s Ark). Cairo: Dār al-Shurūq.

Muhammad 'Abd al-Nabī. 2016. F̄̄ ghurfat al-'ankabūt (In the Spider's Room). Cairo: Dār al-'Ayn. Muhammad Rabī'c. 2015. 'Uțārid (Mercury). Cairo: Dār al-Tanwīr.

(C) Stephan Guth, Dept. of Cultural Studies \& Oriental Languages, University of Olso / Norway 4 stephan. guth@ikos.uio.no 


\section{Father Figures}

On January 29, the Facebook group Șuwar Mașr Zamān ("Pictures from Egypt in the Old Days") posts a photo of Gamal Abdel Nasser (Gamāl 'Abd al-Nāșir), in the company of a young bride and a sheikh. The caption tells a moving story: The girl on the photo is an orphan. She was about to get married but did not have a father or an uncle to act as her guardian during the ceremony. Fearing the judgment of her future husband's family, the girl wrote to Nasser in desperation, explaining her situation. The president soon showed up at her doorstep, bringing along the sheikh of al-Azhar to tie the knot. As one commentator points out, the photo is actually depicting 'Awātifif, the daughter of sheikh 'Abd al-Raḥmān Tāg, on her wedding day. But that does not stop the Facebook crowd from engaging in one of their typical quarrels, which often occur when the name of Abdel Nasser is mentioned. For many, the fictional story captures the essence of the former president. It shows him as a guardian, "a father to all orphans, poor and deprived Egyptian people." Or maybe just a leader who has fulfilled his legal obligations, as one anonymous soul points out, quoting the Prophetic tradition ( $h a d \bar{i} t h$ ): "The sultan serves as a guardian to all those who have no guardian" [ $\nearrow \mathbf{I n}$ Islam...]. To the other half, however, Nasser is synonymous with "tyranny", "oppression", "torture", "defeat in The Six-Day War," "an atheist", "an apostate". In the absence of debate, after 246 comments no consensus is reached on the question of who Abdel Nasser really was. It is the complex relationship with the Father Figure who represents both benevolent guidance and strict authority, which evokes admiration as well as the desire to rebel.

Occasionally both, as 'Awāțif 'Abd al-Rahmān knows very well. The first part of Jīhān al-Ṭāhirī's trilogy Egypt's Modern Pharaohs, screened by BBC Arabic on the anniversary of the 2011 Revolution [ $>$ Memorial days], shows the scholar and journalist talking about Nasser's death:

I was chatting with my brother about Abdel Nasser and the repression. We were saying that he had no option but to be patient for at least twenty more years since Abdel Nasser was young. He was only 51. We were criticizing Abdel Nasser's regime, the Party and its corruption and the Security State. Then I went home. Later, my brother called and his voice was very strange. I said: "What's wrong, Mālik?" He answered: "The President is dead." ... I threw the receiver and lost it. It was horrible, horrible, horrible. Until today I don't think I have ever mourned anyone, including my father and mother, as much as I mourned Abdel Nasser... No one has the right to orphan an entire nation.

Decades after his death, the legacy of the president is still a hot topic, and there is still an apparent need to talk about the events. 'Abd al-Rahmān's comments also touch on the lovehate relationship she has with Abdel Nasser and the battle between the conscious and the emotional. The Father here, with all his positives and negatives, is the one who gives direc- 
tion. Without him, Egypt has no clear path forward, is left without guidance and care, orphaned.

Yet, some go out of their way to show that the direction was actually not lost after his death. On August 27, the Facebook page al-Ra'̄̌s 'Abd al-Fattāh al-Sīsì posts a link to an article entitled "El-Sisi and Abdel Nasser: Two leaders fighting conspiracy" [ $\nearrow$ Conspiracy Theories]. The Americans have a masterplan, aimed at destabilizing Egypt and depriving the country of its independence, the article argues [ $\nearrow$ The Suspect Foreigner]. Under Nasser, they have refused to finance the Aswan High Dam, and have then attacked Egypt after the nationalization of the Suez Canal. Now, Obama's new Middle East plan is again aimed at harming Egyptian sovereignty, making it dependent on aid. And this is just the first part. Once Egypt has fallen, the rest of the Middle East will follow. The only difference, the author concedes, is that in the 1960s, Nasser was only facing external conspiracies. Today, el-Sisi is battling enemies from outside and the Muslim Brotherhood and their supporters from inside the country. Much like Nasser, however, el-Sisi is going to protect the country, ensuring its stability, security and independence [ $\nearrow$ The Voice from Above, $\nearrow$ Security $\boldsymbol{v s}$ Chaos]. He is ready to step in his predecessor's shoes and safely steet the country [ $\nearrow$ Past vs Present, $>$ Past $=$ Present $]$ as long as the people and the political forces are behind him.

But el-Sisi embodies not just a continuation of Nasser's legacy, he is an upgrade. In December 2016, the following anecdote is posted on Khayr ajnād al-ard ("The Best Soldiers on Earth"):

Gamal Abdel Nasser built the High Dam and so he is a leader. Every day, we hear about the projects el-Sisi has completed or is going to complete, but that is normal and no one says a word. These are the words of my mother who is satisfied with you, Mr. President.

The current president does not receive enough praise for his achievements, his accomplishments are merely reported, without elevating el-Sisi to the high status that the ordinary citizen thinks he deserves, as the story suggests, emphasizing on the president's popular appeal. However, it is not just Nasser's legacy that he surpasses. On March 9, the Facebook group Mașr lil-gamī wa-bil-gamī ("Egypt for and through Everybody”) changes its status:

We have a president whose greatness and glory are equal to that of Ahmed 'Urabi, whose courage equals that of Gamal Abdel Nasser, who is intelligent like Sadat and who has true Muslim morals. His name is Mr. Abdel Fattah el-Sisi.

Next to the text is a photo of the president, looking shyly away from the camera. The post is pointing out the virtues of the leader, presenting him as an embodiment of the best qualities of many of the paternal figures from the recent past - the ultimate Father Figure.

Mere admiration is not enough, however. The Father also requires obedience and faith in Him. He promises stability and security — on the condition that His authority is respected. In April, the announcement that the two Read Sea islands of Tīrān and Șanāfïr will be transferred to Saudi Arabia immediately prompts a wave of protests [ $\nearrow$ Red Sea Islands]. But some Facebook users react in a very different way (\#al-Sīsīișāyin-arḍoh [\#elSisi_protects_his_land], \#ad'am-qarārāt-al-Sīsī [\#I_support_el-Sisi's_decisions], \# athiq_fì_al-ra’īs al-Sīsī [\#I_trust_in_President_el-Sisi]). And the proclamation of trust goes beyond the usage of the folk taxonomy mark-up. On April 23, the Facebook group Mașr 
lil-gamī` wa-bil-gamī` illustrates the hashtag \#al-Sīsī șāyin arḍoh (“\#el-Sisi protects his land") with an image, presumably showing scenes from the 2011 Revolution - a building and a truck in flames — with a caption reading: "They [i.e., "the revolutionaries"]...want this Egypt" [ $>$ Downtown]. Immediately below, another picture shows a recently renovated motorway and a photo of a newly built residential block in New Ismailia City

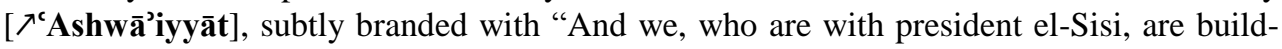
ing this Egypt." The message is clear: stick with the Father who will guide Egypt to greatness and prosperity... or follow "them" on the path to disaster and destruction [ 7 Security vs Chaos]. Yet, the president is not just a guardian and a leader. He is also caring and compassionate. "How can anyone believe that these eyes can sell the land?" asks a Facebook post from April 2016 rhetorically, showing two mirroring images of el-Sisi in tears, separated by a large red heart. Trust el-Sisi by supporting the hashtag, in recognition of the fact that he has sacrificed his life and peace of mind to protect the country! In the comment section, emotions run high. "I love you, Mr. President. Your tears are precious to us," "We love you because you are an officer, we love you because you are a president, we love you because you are tough, we love you because you are merciful..."

An officer, a president, an army man. He could never betray his country. After all, the army is there to protect the land, not sell it. El-Sisi knows best, The Father has a plan for the future of Egypt, he just needs a bit of trust and support from the Egyptian people and everything will be good again. He is a man of the people, a man of the army, and he has never forgotten his duties to Egypt, suggests a post shared on the Facebook page Kullunā rijāl al-shurța al-mișriyya and the comments below it. Proudly carrying the hashtag \#ad'am-qarārāt-al-Sīsī ("\#I-support-el-Sisi's-decisions"), the post also features a remarkable display of affection. To the right there is a photo of el-Sisi in a full military uniform and sunglasses staring at the horizon, a faint smile on his lips. To the left: a heavily armed group of soldiers, posing in front of the Egyptian flag. The president, in civilian clothes, standing in the middle, embraces the soldier kneeling in from of him. One word, written in large Latin characters, floats over the two images: Boba (i.e., Arabic $b \bar{a} b \bar{a}$ 'dad'). A sign of respect and affection, the epithet hints at the president's fatherly appeal, but it also points to another function of his. He is to be obeyed and loved, his authority unquestioned, his fatherly advice always followed [ $\nearrow$ The State $=$ The People] .

As the paternal advice often comes in large quantities, that is not always an easy task.

"What's this rubbish song you put on?," "Don't you have any other clothes?," "Sweat away now, as you did nothing at school," "You are praying five times a day and when I was your age, I was praying seven times a day", "You are now 20. When I was your age, I was more like 22," "Your mom back in the day. Oh, how she chased me" [ YYoung vs Settled].

These are just a few of the memes featuring in a Youm 7 article. The sarcastic lines imitate the manner in which fathers often talk to their sons, while also mocking their know-it-all attitude and tendency to exaggerate. Regardless of time and place, Egyptian fathers have a certain way of talking to their children, which inevitably shows their affinity to overstate the virtues of the past, comparing its style, music and education to that of today. From all memes the same face is staring back: a portrait of a slightly sceptically looking Husnī $\mathrm{Mu}-$ bārak. The political and the biological paternal figure hand in hand. Is he an embodiment of

jais • 17 (2017): 492-498 
all Egyptian fathers or a person whose authority was ultimately rejected? It is perhaps a bit of both, with the ousted president representing all members of the Mubārak generation and their complicated, yet standard, relationship with their offspring [ $\nearrow$ Past $v$ s Present, $\nearrow$ Past $=$ Present $]$.

And complicated this relationship is. The Atlantic celebrates the fifth anniversary of the January Revolution with an article bearing the rather gloomy title "A Revolution Devours Its Children," which follows the life of five Egyptian families who have close relatives detained on political charges [ $>$ Disappearances]. Heavily appropriated for a foreign audience, the piece delves into the stories of the five families, all trying to cope with the absence of their loved ones. Most of it revolves around the daily struggles: the long queues at the prison, the weekly 20-minutes-long visitations, the pain of (not) knowing what the future holds [ $\nearrow$ Prison]. Inevitably, some of the conversations move towards the reason for the detention, revealing a generational clash. "This generation wants to live their life, in their own style," "Nūrhān started to feel that she and Ahmad belong to one team, and that we belong to a different team," "His father told him then that the country's youth were foolish, that the 'deep state' would prevail," recalls the mother of the detained activist Ahmad Dawma. The past few years have put a rift between the family members who disagree on what the right path for Egypt is, especially after Ahmad's father publicly supported his son's arrest by the Muslim Brotherhood in 2012. Despite now sharing a common enemy, the family remains divided by a deep sense of mistrust. However, not just politics but also the absence of it could create a gap between family members. Two years ago, in April 2014, 21-year-old Muhammad Imām, according to his friends a member of the April 6 Youth Movement, had been arrested following a protest at the University of Alexandria. His father, a retired military officer, now has a different story to tell. "We are not allowed to get involved in politics," "Me, I don't have any opinions on all that." He has not visited his son in prison yet. "Nothing is wrong with Egypt," Muhammad's mother adds, "We're not a politically interested family, we don't like politics, we don't even know what April 6 is." The guidelines for the family's political and social conduct are set. Having failed to follow the advice to respect the authority of the paternal figure, the sons have been punished by both the actual and the figurative fathers. [ $/$ True vs False, $\nearrow$ Voice vs Silence, $\nearrow$ Past $=$ Present $]$

Not that the relationship is any simpler at the other end:

When you meet a male friend while you're with your parents somewhere and you guys make that awkward eye contact that means DO NOT DO CHEEK KISSES, DO NOT DO HUGS; only stiff handshakes are allowed. In fact, if you can limit touching altogether, all the better. Baba is watching,

states number three on the list of "Fifteen Egyptian girl problems," posted on Cairoscene. Between having to ask the father's permission to go away for the weekend and having to justify that in front of foreign friends, the life of the Egyptian girl is tough. Questions about marriage, comments about cooking skills, and constant monitoring of their whereabouts are just part of the things girls have to endure from their parents. All coupled with having to pretend to abide by rules with which they clearly disagree. "The fuck do I care what the bawwāb thinks? ... Apparently everybody's primary concern in life is to scrutinise yours", bellows the author defiantly [ $\nearrow$ Voice $v$ s Silence, $\nearrow$ Young $v$ s Settled]. A showcase of the 
double lives children often live because of their parents, torn between compliance and rebellion, both respecting and challenging the authority of the Father Figure and the social system it represents [ $\nearrow$ Dual identities / Masking, $\nearrow$ True vs False].

And they are questioning the rationale behind the various rules of civility. Blogging for Madā Mașr, Hiba 'Afifi gives her take on the issue. Soon it will be Ramadan again, the month of soap-watching marathons and endless awkward social events that are impossible to avoid, Ifțàr meals, for instance, accompanied by painfully long forced conversations with people with whom you have nothing in common. And it is not just Ramadan that brings out the worst of social obligations. Being forced to attend weddings and funerals of distant relatives and acquaintances whom you barely know also creates this feeling of unnecessary intrusion in people's personal space [ $\nearrow$ Freedom $\boldsymbol{v s}$ Constraint, $\nearrow$ Individuality vs Collectivity]. The case, of course, is not against all social gatherings. Rather, the problem is with social obligations that only serve the purpose of maintaining appearances and upholding archaic social rules. Isn't it time to stop clinging to a lifestyle that contradicts its original intention of creating deep and meaningful relationships? Or, to paraphrase the words of Cairo rock band Cairokee:

There are traditions that become defects and need to be changed. Freedom means change, how to express yourself is your choice and not somebody else's. Things are not going well. The old man is trying to bring the past back, while controlling the present $[\ulcorner$ Past $=$ Present $]$. The whole society is united against change, but they can't take away the voice of the people.

An unruly cry against all those who try to restrict freedom and impose their own ideas on the rest [`al-Muwāțin al-sharīf]. All those who control life, all old men, all Father Figures.

"Long live Egypt... Long live Egypt... Long live Egypt," explodes the conference hall as el-Sisi prepares to give the concluding speech of the First National Youth Conference. "I am very happy to be among my sons and daughters, the youth of Egypt," begins the president. The last few days have demonstrated, he continues/elaborates, that the young people of Egypt are capable and enthusiastic and that through receiving proper training, advice and guidance they can become a driving force of Egypt of tomorrow. The country is young, and the youth represents national wealth, which should be developed and invested in. The government will work towards reviewing the status of the detained young people (applause!), developing training programmes, discussing amendments in the Protest Law and ensuring the continuation of Egypt's cultural and historical identity. The youth population, el-Sisi goes on, has been somewhat neglected and marginalised. But Egypt belongs to everyone and only those who want to do harm have no place here. He, the President, will work with all young people because a father loves all his children and he hopes that one day one of the young Egyptians will take his place. "Long live Egypt... Long live Egypt... Long live Egypt," concludes the protector, provider and supporter, the father of the youth of Egypt.

El-Sisi will work with all young people? But where is this youth he is talking about?, Egyptians ask themselves on Twitter, after the hashtag Where is the youth? explodes yet again on the platform. "Behind bars or buried in their graves," the answer comes. "If el-Sisi held his conference in prison, there would have been a larger attendance," jokes one Egyptian, as many others share pictures of the young people detained, sentenced or killed since

jais • 17 (2017): 492-498 
2013 [ Disappearances, $\nearrow$ Prison, $\nearrow$ Young $v s$ Settled]. "I have a message for you...”, says a drawing of an overweight Egyptian official, as he pokes his head through the barred door of a prison cell, with the words "Egyptian youth" next to it, "You are the hope and the future of Egypt" [ $\nearrow$ Satire]. The Egyptian youth needs actions, not words, it is time for real change, not empty promises. The young Egyptians are fed up with the "Father" discourse and the words that fail to deliver in practice. Acting like an almighty figure of authority is no longer enough, the role of the father-leader is becoming obsolete.

"The Egyptian youth are children only to their parents," rails 'Umar al-Hādī from the virtual pages of al-Mașri al-Yawm. Again, this critiques the notion of the "FatherPresident" which has been harming Egypt for decades. The young are not the president's children, they are citizens with rights and obligations. They demand freedom and dignity and el-Sisi addressing them as his sons and daughters is just an insult. Treating them as children who need presidential advice is not going to solve the youth crisis. The country's restraint towards the people has been great during the last few years, states el-Sisi, to avoid the current state of tension. How come? Is he forgetting that the state is the state of the people? Is he forgetting the great self-restraint people had to impose on themselves when dealing with the actions of the regime? [ $\nearrow$ Baby milk, $\nearrow$ Dollar crisis]. The angry monologue continues: The people have not wrecked the Egyptian economy, they have not ignored the problems in the security services until the crimes committed by policemen occupy half of the incident page in al-Ahräm, they did not transfer the two islands to Saudi Arabia [ $\nearrow$ The Police(man) criminal, $\nearrow$ Red Sea Islands, $\nearrow$ Tricked by the system]. The people did not kill Giulio Regeni and they did not imprison Aḥmad Nāgī for his comics and Islam Behery (Islām Buhayrī) for his ideas [ $/$ Prison]. Egypt needs a state that respects the constitution and the rights and the freedom of its people. The Egyptians want a president of a modern secular state and not a father, a leader or a caliph. Al-Hādī’s final remark brings the tirade to an abrupt stop, leaving the reader suddenly aware of the emotional charge of the words and the power of the silence that follows. It is not just a rejection of el-Sisi but of the entire notion of the Father Figure, in all its complexity, and the social and political system built around it.

\section{Related Entries}

Arrays: 'Ashwā'iyyāt, Baby milk, Conspiracy Theories, Dollar Crisis, Downtown, Disappearances, In Islam..., Memorial days, al-Muwātin al-sharīf, The Police(man) criminal, Prison, Red Sea Islands, Satire, Suspect Foreigner, The Voice from Above, Tricked by the System. Codes: Freedom vs Constraint, Individuality vs Collectivity, Past vs Present, Security vs Chaos, True vs False, Voice vs Silence, Young vs Settled. Codes collapsed: Past $=$ Present, The State $=$ The People $($ Police state $)$

\section{References}

The Atlantic, A Revolution Devours Its Children, $23^{\text {rd }}$ January 2016, <https://www.theatlantic.com/ international/archive/2016/01/egypt-revolution-arab-spring/426609/>.

Cairokee, "Ākhir ughniyya," $12^{\text {th }}$ March 2016, <https://youtu.be/TZu2euuj2GE>.

Cairoscene, "15 Egyptian girl problems you can probably relate to," April 2, 2016, <http:// www.cairoscene.com/LifeStyle/15-Egyptian-Girl-Problems-You-Can-Probably-Relate-To>. 


\section{Mihaila Yordanova}

Jīhān al-Ṭāhirī, Egypt's Modern Pharaohs, available on YouTube, posted $26^{\text {th }}$ January 2016, $\langle$ https://youtu.be/YvZ_ngOvsgk>.

"Khayr agnād al-arḍ," Facebook post, December 28, 2016, <https://www.facebook.com/Khair. Agnad. Elard/posts/1649053595110028>.

"Kullunā rijāl al-shurța al-mașriyya," Facebook post, April 11, 2016, <https://www.facebook.com/ elking.mohamed.89/photos/a.393231024089612.94224.393222587423789/998128573599851>.

Madā Mașr, "The case against social obligations," July 28, 2016, <https://www.madamasr.com/en/ 2016/06/20/opinion/society/blog-the-case-against-social-obligations/amp/>.

"Mașr lil-gamî̃ wa-bil-gamî̄," Facebook post, March 9, 2016, <https://www.facebook.com/ 1Tamer.Asfour/photos/a.363452263709580.90414.152451254809683/953258231395644>.

"Mașr lil-gamī' wa-bil-gamī'," Facebook post, April 23, 2016, <https://www.facebook.com/1 Tamer. Asfour/photos/a.363452263709580.90414.152451254809683/985198328201634>.

"al-Ra'̄is 'Abd al-Fattāh al-Sīsī," Facebook post, August 27, 2016, <https://www.facebook.com/ 73sisilovers/posts/1753242544926260>.

“\#al-Sīsī șāyin arḍoh”, Facebook post, April 12, 2016, <https://www.facebook.com/permalink. php? story_fbid $=10153699358054790 \& i d=529354789$ >

al-Sīsī speech, First National Youth Conference, October 27, 2016, 〈https://youtu.be/asIPXP5uI1Y>.

"Ṣuwar Mașr Zamān," Facebook post, January 29, 2016, <https://www.facebook.com/sewarmisr/ posts/755518071249270>.

Twitter, "il-šabāb fēn?" Most popular hashtag on October 26, 2016, <https://twitter.com/search? vertical=default\&q=\%23\% فين_الثباب>>

'Umar al-Hādī, "al-shabāb muwāṭinūn ... wa-laysū abnā’-ak," al-Mașrī al-Yawm, October 27, 2016, <http://www. almasryalyoum.com/news/details/1031314>.

Youm7, "10 gumal ta'kis țabī'at al-ab al-miṣrī al-așīl: bi-ṣawt Ḥusnī Mubārak," February 11, 2016, بhttp://www.youm7.com/story/2016/2/11/2579862/بالصور_10_جُمل_تعكس_طبيعة_الأب_المصرى_

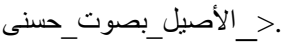

(C) Mihaila Yordanova, Dept. of Cultural Studies \& Oriental Languages, University of Olso / Norway 4 mly201@yahoo.co.uk 


\section{Psychiatrists}

"Hi, welcome to Shezlong. We are the support team; how can we help you?" The question pops up directly when you enter the website Shezlong.com. On the other side of the screen, professional psychiatrists are ready to help those who seek help online to handle their mental illness. Only one year after the launch of the online psychiatry platform, 14.000 people all across the Arab world get treatment in sessions conducted via chat or video calls. Half of these clients are from Egypt.

Millions of Egyptians - an estimated sixth of the whole population of over 90 millon-suffer from mental disorder without searching or receiving treatment for their psychological problems, neither from the 6.000 psychiatrists that are there in the country there ( 1 per 15.000 !), nor through digital platforms. The huge discrepancy between psychological suffering and actual treatment is often explained by the societal taboos regarding mental health disorders. The founder of Shezlong tells journalists that he believes the guaranteed anonymity and decreased risk of being socially stigmatized are key to the success of his website.

But it is not only online that psychiatrists appear, they also play a role in various forms of popular culture. In the literature scene, several psychological self-help books gain popularity [ $\nearrow$ Self-help]. A little stand at the Cairo International Book Fair of February is dedicated to the General Secretariat of Mental Health, a governmental organ that has recently launched a campaign to raise awareness about mental diseases. On the book fair, psychiatrists distribute pamphlets to passers-by who dare to stop by their stand. On a more grass-root level, a psychiatrist and professor from al-Minyā's Faculty of Medicine gains popularity among Egyptians. Through the regular postings on his Facebook page and in his bestselling self-help books written in colloquial Egyptian [ $\nearrow^{‘} \bar{A}$ mmiyya], Muhammad Ṭāhā encourages his readers to analyze their relationships with other people. Only then will they be able to see what role they play in these relationships themselves, and only then will they discover their true and false selves [ $\nearrow$ Dual identities]. His book il-Khurūg 'an il-naș ("Out of the Box") becomes one of the bestselling "social books" of the year, and he also attracts large numbers of people to the dozens of lectures he gives in the country's biggest cities. The book signing sessions after each of these lectures are thoroughly documented with pictures on the Facebook pages of these events, revealing a majority of female attendees.

One topic often repeated by the popular psychiatrist is the view that oppression of a child's psychological needs will, in a later stage of life, inevitably affect the grown-up person's mental health in a negative way. A worst-case scenario in which the mentally ill person commits crimes is portrayed in several Ramadan series. In one of them, Suqūt Hurr ("Free Fall"), several of the main characters' psychological suffocation is caused by neglecting themselves or others.

The characters' sessions with the psychiatrist shed light on the internal conflicts within the series' storylines and enable both internal and personal conflicts to develop. The 
positive development of characters is often in line with the psychiatrist's advices. The character Sihām, a woman in her late fifties, approaches her daughter Malak's psychiatrist in order to understand why Malak killed her own sister and husband. Sihām's problems with Malak and other family members have become apparent for the spectators, since this scene is in the ninth episode of the 30 -episode series. She is skeptical and suspicious towards the psychiatrist and only visits him to learn what her daughter has told him, but not her. The psychiatrist tells her that he is not allowed to reveal any of Malak's secrets, but he assures her that he had not been informed about Malak's plans to kill her husband. He invites Sihām to come back if she wants someone to talk to. Later in the series, Sihām regularly goes to see the psychiatrist, complaining about how difficult it was to raise two children on her own. Using thought experiments, the psychiatrist challenges her perception of a society that puts her in a box and defines how she should behave towards her children, namely like a tough father. He tells her that it was she herself who chose to fit into this miserable box that she thought society put her in: first as a strict and lone, then a strict and widowed mother. He claims that she has been tough on herself and her daughters in vain and rhetorically asks Sihām if Malak's illness could be the result of being neglected in her childhood. Sihām's self-diagnosis is that her anxiety prevented her from feeling anything at all, and from feeling like a woman in particular. She tells the psychiatrist that when a woman does not feel safe anymore, she stops feeling like a woman. She furthermore asserts that society would have condemned her if she spent her time, as a widowed mother, to look for a new man. The psychiatrist, while acknowledging that Sihām's choice of not looking for a new man is well-respected in society, claims that the widowed women who choose to remarry could raise their children in a likewise proper manner as the ones who remain alone.

Although societal constraints are acknowledged in Suqūt Hurr, it is up to the individual to choose whether to obey them or not. The personal does not become political as the struggle against societal structures is reduced to a fight with oneself, maybe with the guidance of a psychiatrist. If Sihām chose to take the easy way and adapt to what she thought was her role in society, it was all her fault. By the use of the psychiatrist as a moral compass in this particular Ramadan series, not turning crazy is seen as each and every individual's own responsibility.

However, the portrayal of the psychiatrist is not always positive. In Suqūt Hurr, as in Fawq Mustawā al-Shubuhāt ("Above Reproach"), another series in 2016 that uses the psychiatrist and a mentally disturbed person as points of departure, psychiatrists are repeatedly violating the duty of confidentiality as they are discussing their clients with friends and family or even believed to record the sessions. Whether this lack of work ethics is a portrayal of reality or believed reality, the audience might in the end feel more tempted to checking out the more anonymous online alternative to the psychiatrist's chair.

\section{Related entries}

Arrays: 'Āmmiyya; Dérja; Dual identities; Self-help. 


\section{References}

"Ashhar 10 kutub li-'ām 2016" ("The 10 most popular books of the year 2016"), Iqraaly, retrieved from <http://iqraaly.com/blog/post/5> (as of January 6, 2018).

Na'ūm, M., and W. Hamdī, Suqūt Hurr ("Free Fall”), 2016, El-Adl Group, retrieved from <https://m. youtube.com/playlist?list=PLk7aOjrbxuopKM6YtvnoCme4MQNmmi0Zz> (as of January 7, 2018).

Quwaysī, S., "Ta'arraf 'alà qā̉imat al-kutub al-akthar mabī'an fì Mișr 'ām 2016” ("Get to know the list of the best-selling books of 2016 in Egypt"), retrieved from $<$ https://www.ida2at.com/bestselling-books-in-egypt-2016/> (as of January 6, 2018).

Talaat, N., "Egyptian Startup Fights Depression Online,” Al-Monitor, December 19, 2016, retrieved from <https://www.al-monitor.com/pulse/originals/2016/12/egypt-online-startup-fight-depressionshezlong. html> (as of January 6, 2018).

TEDx Talks, "The Four Steps Model towards Psychological Health | Dr. Mohamed Taha | TEDxWadiElrayan", YouTube video, November 15, 2016, retrieved from <https://m.youtube.com/watch? $\mathrm{v}=\mathrm{GmV}_{-}$9BBNIj0> (as of January 6, 2018).

(C) Maren Buvarp Aardal, Dept. of Cultural Studies \& Oriental Languages, University of Olso / Norway $\checkmark$ marenaardal@gmail.com 


\section{Satire (on YouTube channels)}

On Monday, January 25, hundreds of police troops guard Tahrir square in the context of the celebrations of Police Day [ $\nearrow$ Memorial Days/Commemoration]. This year's Police Day coincides with the fifth anniversary of the Egyptian revolution of January 25. Tough security measures in the Egyptian capital in anticipation of any demonstrations make the day more representative of the state institutions than of the people's revolution. In this atmosphere, and among the heavy troops, the young actors Aḥmad Mālik and Shādī Husayn blow a number of condoms to appear in the form of balloons, writing on them the words: "From the people of Egypt to the Police Forces on January 25," and distribute them to the police.

After recording a video of the process of blowing the condoms, writing the slogan and distributing the fake balloons to the police, Ahmad and Shādī post the video on YouTube [־Social Media] and on their Facebook site. Shādī Husayn, who works as correspondent for the comedy TV show Abla Fāhìtā, writes on his Facebook site: "In this freezing cold we decided to celebrate Police Day." About an hour after publishing the video, he adds: "As long as neither demonstrations are allowed nor opposition can be voiced, you will be our object of ridicule. Even if we die, we will continue to make fun of you. I hope you enjoy the event" [ $\nearrow$ Us vs Them]. For 'to make fun of you', Shādī uses the Egyptian colloquial verb safflyisiff (which is derived from the Standard Arabic saffahalyusaffihu 'to deride and depreciate' a person or an opinion) [ $\nearrow^{`} \overline{\mathbf{A}} \mathbf{m m i y y a}$. The word is a distinct marker of youth language; it often goes together with ?allish/yi?allish 'to make a humorous comment on s.th.', a term that is taken from the football lexicon, where it describes a ball missing its target [ $\nearrow$ Football]. Missing the target, i.e., deviation from the norm, seems to stimulate laughter.

The only way of celebrating allowed by the state on Revolution / Police Day is an acclamatory appreciation of the security forces, together with them. Shādī and Mālik stay within these limits [ $\nearrow$ Dual identities]. In the absence of freedom to publicly express one's political opinion, their action represents a 'symbolic counter-attack' through verbal satire and humorous stunt, a practice that meets with wide approval judging from how quickly their video spreads on social media. This expresses frustration over the current marginalization of opponents, as compared to the active involvement in public affairs and the diversity of voices that had characterized the revolutionary days [ $\nearrow$ Past $v s$ Present]. Egyptians draw on a long history of combating such frustration with humour and sneer.

The video gets more than one million hits in one day and a flood of comments. In one of them, Bāsim Yūsuf, the 'father' of YouTube shows and icon for those following in his footsteps, writes: "Well done, Shādī! By law and constitution, you did not commit a crime." On social media, a polemic discussion unfolds among those who support the idea of the satirical stunt as a means of expressing opinion, and those who consider it an insult to the police [ TTickling Giants / Pillit adab]. A few days later, a police officer uploads a 
video to YouTube expressing his disapproval of the event; in his opinion, it lacks the reverence that is due to the police forces.

Talk show presenters Aḥmad Mūsà and 'Amr Adīb launch a campaign against Shādī and Mālik in which they call for penalising them. In contrast, the TV comedy shows Abla Fāhìtā and Abū Hafiza consider it a moment of recklessness that should be permitted for the sake of freedom of speech. After a short interval needed for the creation of new episodes, also YouTubers join the debate. On February 1, Aḥmad Buhayrī uploads a new episode to his $I l-U s b \bar{u}^{c} f \grave{\imath} k \bar{l} s$ ("The Week in a Bag"), a channel that presents commentaries on the top news of the week. The title of this episode, "il-'Askarī fìh kitāb dīn" ("The soldier has a religion book on him"), is a parody (?alsh) of a sentence that is common among Egyptian children: il-shanța fĭhā kitāb dīn ("There is a religion book in my bag"), usually said to prevent other children from messing with one's property. The metaphor presents a satirical comment on the meaning of the untouchable soldier that the talk show presenters, Lamīs al-Hadīdī and Tāmir Amīn, argue for. In the same vein, Ashraf Hamdī, the popular YouTuber and cartoon film creator, gives his animation film the humorous title Ihna bitūc il-balālīn ("We are the Balloon Guys"), resembling the title of one of 'Ādil Imām's movies (Ihna bitū' il-ūtūbiss, "We are the Bus Guys"). In the compressed style of a cartoon-like sketch, the episode stages the encounter of two main characters (= roles), Hamāda (= Egyptian youth) and a police officer (= police forces), and their conversation at one of the notorious check points [ $\nearrow$ Check-points/kaminn]. As usual, the immediate motive for the police officer to stop the youth remains unclear. As the officer searches Hamāda's pockets, he notices a Facebook account on the screen of his mobile, which means that he may be an activist. The young man feels the crisis; people have been arrested before for "unlicenced use of Facebook". When the officer also finds a balloon in Hamāda's pocket, this confirms his suspicion and seems to answer the question to which group Hamāda belongs: the police officer calls for a patrol to arrest the young man who "belongs to those who inflate balloons". The caption below the video states that it is a response to what has come to be known as the "Condom Incident": In the first week of February, police search the office of the well-known cartoonist Islām Gāwīsh, asking for software licences and a permit to use a Facebook account for the distribution of media material. Since Gāwīsh does not have such papers in hand, he is arrested and his computers are confiscated. For many followers of Gāwīsh's Facebook page il-Waraqa, the missing licences are only a pretext-it is his satirical cartoons that provoke those in power $[\nearrow$ Condom Incident, $\nearrow$ The System $v s$ The People, TTickling Giants / Pillit adab].

In contrast to political satire, reflection on media materials presented on local TV channels is the central theme for the YouTubers Hishām 'Afïfī and Sālīzōn. 'Afîfî's YouTube show, al-Tahlīl al-istrâtīgì ("Strategic Analysis"), is a humorous analysis of the plot and the visual design of selected advertisements and video clip songs, based on parody, which replaces the original lyrics with unrelated content, a technique with which 'Afifi manages to stimulate vivid laughter. In contrast, Sälìzone deals with Ramadan TV series. The moderator elaborates on the contradictions in the narration and errors in scene recording. After Ramadan, both Sālī and Hishām dedicate their episodes to commenting on TV talk shows on local channels [ $\nearrow$ True vs False]. The window by which Sāli sits joking with a guest about the absurdity of her experience on TV has become iconic: through the window, fresh air and fresh ideas come in. 
Social criticism, especially of the Egyptian family, is the central theme for Shādī Surūr. In the humorous sketches of his popular YouTube channel, he satirizes patterns of behaviour among sons and parents. One frequent stereotype is the strict father who suppresses his son's choices and his aspiration to try out new things [ 7 Father Figures]. Surūr's caricature of the father who prevents his son from watching video clips on TV while he himself enjoys watching the same content in his room exposes parents as humans with shortcomings. However, despite these flaws, life goes on, with a generation gap in values and perceptions [ $\nearrow$ Young $\boldsymbol{v s}$ Settled].

Another mode of satire can be the assembling of the most circulated sentences in the streets of Cairo in a creative collage that becomes the script of YouTube episodes. With simple equipment—only a mobile phone camera [`Mobile Phones] — the Ațâl Shawāric (Street Children) band manages to attract hundreds of thousands of followers to their satirical YouTube channel. Six young actors, mostly under 25, together perform a type of street theatre. The tallest member holds the phone camera to film the videos in a selfie style, while the band chant their satirical text. It builds on contradictions in political and social expressions in everyday life and on TV channels. Muhammad 'Ādil, one of the band's members, says: "What we do is just a collage of what people are saying in public, rearranged to highlight the paradoxes in our lives that make people wonder how this happens without notice... The street is full of [things that provoke] laughter." In January, they upload their first video, entitled "Barā'im al-İmān" ("Buds of Faith"), criticising the stagnant programming on the Noble Qur'an Radio station. For almost forty years, programs have the same introduction, topics and closure. In order to remedy the lifeless monotony that has befallen this radio station, 'A dil quotes the introductory sentences of some of the programs and chants them in a mechanical way to parody the original. In response to Ațâl shawāric', Azharī scholar Aḥmad Karīma condemns their comedy video as an insult to Islam [ $\boldsymbol{\gamma} \mathbf{I n}$ Islam...]. Undeterred, in their second video they put together segments of patriotic songs performed before background scenes that evoke contrary meanings — black, or at least dark, humour.

\section{Related Entries}

Arrays: 'Āmmiyya; Check-points/kamīn; Dual identities; Father Figures; Football; In Islam...; Memorial days/Commemoration; Mobile Phones; Social Media $\bullet$ Codes: Past $v s$ Present; Superiority vs Inferiority; The System vs The People; True vs False; Us vs Them. Codes collapsed: Past $=$ Present $($ Stuck)

\section{References}

(All online references were last accessed in December 2017).

Aḥmad Buhayrī. (2016, Feb. 1). "Il-'Askarī fīh kitāb dīn" ("The Soldier is Carrying a Religion Book on Him"). Episode of YouTube channel $I l-U s b \bar{u}^{c} f \grave{\imath} k \bar{l} s$ ("The Week in a Bag"). Retrieved from <http://bit.ly/2FtUP16>.

Aḥmad Darwīsh. (2016, Dec. 23). "Widā'an li’l-nukta al-mișriyya” (“Goodby Egyptian Jokes”). Rașîf 22. Retrieved from <http://bit.ly/2nlTm9Y>.

Ațfāl Shawāric. (2016, Jan. 7). "Al-fîdiyō al-awwal: Barācim al-Īmān" ("The First Video: Buds of Faith”) [Videofile]. Retrieved from 〈http://bit.ly/2E1Fw5W>. 
BBC Arabic. (2016, Jan. 26). "Mā 'l-qișșa warā’ fìdiyō 'Bālōnāt al-wāqī al-dhakarī’ alladhī athāra jadalan fi Mișr?" ("What is the story behind "The Condom Incident' video" that caused a stir in Egypt?"). Retrieved from <http://bbc.in/2liRu0m>.

Dot Masr. (2016, Feb. 5). "Fīdiyō | Abū Ḥafìza yataḥaddath 'an 'al-Wāqī al-dhakarī’ wa-'al-Waḥsh al-Mișrī”" ("Abu Hafiza talks about the 'Condom Incident' and 'The Egyptian Beast"'). Retrieved from <http://bit.ly/2FrA5KA>.

Egyptoon. (2016, Feb. 13). "Iḥnā bitūc il-balālīn" ("We are the balloon guys"). [Videofile]. Retrieved from <http://bit.ly/2lqjuyA>.

Hesham Afifi [Hishām 'Afîfi]. (2016, Oct. 11). "I'lān Bank Sāyib” (“Advertising Bank Saib”). alTaḥlìl al-istrātīgī ("Strategic Analysis"). [Videofile] Retrieved from <http://bit.ly/2EnXRIn>.

— . (2016, Aug. 13). "Ithbāt anna al-aghānī al-ajnabiyya aṣluhā 'arabī ("Proving that foreign songs have Arabic origins"). [Videofile] Retrieved from $<$ http://bit.ly/2GvKpCO $>$.

Indiyānā Khālid. (2016, Jan. 31). "Shāhid... 15 șūra tasabbabat fĩ al-qaḅ̣ 'alā Islām Gāwīsh 'alWaraqa"" ("15 caricatures that caused the arrest of Islam Jawish of 'al-Waraqa"). Al-Dustūr. Retrieved from <http://www.dostor.org/974407>.

Șadā al-Balad. (2016, May 14). "D. Aḥmad Karīma yarfự al-ifrāj 'an Aț̣āl al-Shawāric wa-yuțālib al-nā’ib al-'āmm bi-muhākamatihim | 'alā mas'ūliyyatī” ("Dr. Aḥmad Karīma refuses to release the 'Street Children' band and demands the public prosecutor to bring them to court $\mid$ On my responsibility"). [Videofile]. Retrieved from <http://bit.ly/2EmOXdV>.

Sālīzōn. (2016, Oct. 22). Sālīzōn al-Mawsim al-thān̄: gharā’ib wa-țarā’if Ramaḍān 2016 ("Salizon The Second Season: Weird and funny moments from Ramadan [soap operas] 2016”). Retrieved from <http://bit.ly/2nraKcz>.

Shādī Surūr. (2016, Jul. 24). "Lammā abūk yi'raf innak nagaḥt fî 'l-Thānawiyya il- 'Āmma" ("When your father learns that you have passed the High School exams"). [Videofile]. Retrieved from <http://bit.ly/2FsSXsJ>.

Ten TV. (2016, Jan. 26). "Masāà al-Qāhira - Ḍābiṭ shurța yarudd 'alā fìdiyō ihānat rijāl al-shurța bi'wāqī dhakarī’ min Aḥmad Mālik wa-Shādī Huusayn" ("Cairo Evening - A police officer comments on the condom video insulting police officers by Aḥmad Mālik and Shādī Ḥusayn"). [Video file]. Retrieved from <http://bit.ly/2FqNOS7>.

(C) Mohab Mohamed, Dept. of Cultural Studies \& Oriental Languages, University of Olso / Norway $\triangleleft$ mohab.mohamed@ikos.uio.no 


\section{Notes}

Introduction: From "Issues" to "Arrays" (S. Guth \& A. Hofheinz)

1 For a discussion of our approach in the context of others in an "Academia in Transformation" (to quote the title of a research initiative of the Arab-German Young Academy of Sciences and Humanities, AGYA), see Barbara WINCKLER and Christian Junge, "Opening Up the Text: Arabic Literary Studies on the Move," Arab-German Young Academy of Sciences and Humanities (AGYA) - Transformation Group, Working Paper No. 2/2017, available from <http://agya.info/fileadmin/user_upload/Working Groups-images/Transformation/WPS_Academia_in_Transformation/Paper_7_Opening_up_the_Text_ Winckler_Junge.pdf $>$.

2 Free pdf available from <https://monoskop.org/images/9/95/Gumbrecht_Hans_Ulrich_In_1926_Living _on_the_Edge_of_Time.pdf $>$.

3 "atmosphere, mood, spirit, vibe, ..."-a key word in Gumbrechtian thinking that is difficult to translate, which is why the author himself usually prefers to leave it untranslated. See especially his Stimmungen lesen: Über eine verdeckte Wirklichkeit der Literatur, München: Hanser Verlag, 2011 (translated into English by Erik BUTLER as Atmosphere, Mood, Stimmung: On a Hidden Potential of Literature, Palo Alto: Stanford University Press, 2012). Cf. also the public lecture "The dimension of 'Stimmung' in contemporary popular culture," given on December 13, 2016, in Minsk, available on YouTube: <https://youtu.be/t_dajId2BaA>.

4 Much of the material was collected in a shared researcher's notebook, using Evernote (https:// evernote.com).

5 The "special dossier" Living 2016: Cultural Codes and Arrays in Arab Everyday Worlds Five Years After the "Arab Spring," edited by Stephan Guth and Elena Chiti, appeared as pages 221-388 of JAIS, 16 (2016), and is accessible both at JAIS's previous website (http://www.hf.uio.no/jais/volume/ vol16/v16_09_living2016.pdf) and at the new pool of open-access journals hosted by the University of Oslo, see <https://www.journals.uio.no/index.php/JAIS/article/view/4761>.

6 The list, processed from the data collected in our researcher's notebook as well as from the studies contained in the Living 2016 dossier (see previous note), is given on pp. 229-33 of Stephan Guth, "Introduction: Living 2016 and the In 2016 project," JAIS 16 (2016): 224-33.

7 GUMBRECHT 1997: 434.

8 Ibid. (our emphasis, S.G./A.H.).

9 Ibid. (dto.).

10 Ibid. (dto.).

11 Ibid. (dto.).

‘Āmmiyya (E. M. Håland)

1 My translation - E.M.H.

\section{Clash (E. Chiti)}

1 Andeel, "Al-'adāla li'l-jamī'", Mada Masr, 11 February 2016: <https://www.madamasr.com/en/2016/ 02/11/cartoon/u/justice-for-all/>.

2 Fieldwork notes, January-February 2016.

3 “Al-yawm... ințilāq ma'raḍ al-Qāhira li'l-kitāb," Al-Shurūq News, January 27, 2016: <http://www. shorouknews.com/news/view.aspx? cdate=27012016\&id=fe442bc5-e180-45fa-afaa-745f748240bf $>$.

4 “Tajribatu-hu maca 'l-Ikhwān fī ḍayf al-sharaf," Akhbār al-Adab, February 14, 2016: 6. 
5 Fieldwork notes, Round Table Al-thaqāfa fî'l-muwājaha, Cairo Book-Fair, Main Hall, January 29, 2016.

6 Shahira Amin, “Three years on, wounds of Egypt's deadly sit-in dispersals linger," Al-Monitor, August 21, 2016: <https://www.al-monitor.com/pulse/originals/2016/08/egypt-three-year-anniversary-rabaa-sitin-brotherhood.html>.

7 “'I was terribly wrong' - writers look back at the Arab spring five years on," The Guardian, January 23, 2016: <https://www.theguardian.com/books/2016/jan/23/arab-spring-five-years-on-writers-lookback>.

8 "Ishtibāk: fīlm miṣrī fī iftitāḥ mahrajān Kān,” al-Ahrām, May 13, 2016: <http://gate.ahram.org.eg/ News/978271.aspx>.

9 Thomas Sotinel, "Clash : après le bus 678, le fourgon de police," Le Monde, May 12, 2016: <http:// www.lemonde.fr/festival-de-cannes/article/2016/05/12/clash-apres-le-bus-678-le-fourgon-de-police_ 4917875_766360.html>.

$10<$ https://twitter.com/moezmasoud/status/730910281442971649>.

11 TV show Anā Maṣrī, ḥalqat "F̄̄lm Muḥammad Diyāb Ishtibāk, bi-nakha siyāsiyya wa-thawriyya”, May 15, 2016: <https://www.youtube.com/watch?v=SiwWQxmP5WQ>; see also: <https://www.youtube. $\mathrm{com} /$ watch? $\mathrm{v}=-$ lmutjpDCBA>.

12 "Tom Hanks and Daniel Craig Express Their Love for Egyptian Movie 'Eshtebak", Scoop Empire, July 26, 2016: <http://scoopempire.com/eshtebak-tom-hanks-daniel-craig/>.

13 Aḥmad Midhat, "Mā lā ya rifu-hu Tom Hanks," Masralarabia, July 30, 2016: <http://www.masralarabia.

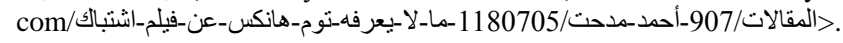

14 Sāmiḥ Faraj, "Ințibāeāt sarî‘a 'an fìlm Ishtibāk", Za2ed18, July 31, 2016: <http://www.za2ed18. com/إنطباعات_إذا؟_نشتبك-من-مع-يكتب_فر ج-سامح>>

Conversions (M. Lindbekk)

1 “'Āwiz tighayyir diyāntak fĩ Mașr, ibqà qābiln̄̄,” al-Șabāh, April 12, 2016, <http://www.elsaba7.com/ NewsPrint.aspx?Id=142416> (accessed November 1, 2017).

2 al-Buḥayrī, Aḥmad, "Shaykh al-Azhar: Ḥurriyyat al-i'tiqād shay’ wa-ḥurriyyat al-irtidād shay' ākhar," al-Mișrī al-Yawm, June 16, 2016, <http://www.almasryalyoum.com/news/details/965579> (accessed November 1, 2017).

3 “Āēwiz tighayyir diyāntak fī Mașr, ibqà qābiln̄i,” al-Șabāḥ, April 12, 2016, <http://www.elsaba7.com/ NewsPrint.aspx?Id=142416> (accessed November 1, 2017).

4 Ibid.

5 Egypt Independent: "Egypt's Jewish community diminished to 6 women after death of Lucy Saul," July 30, 2016, <http://www.egyptindependent.com/egypt-s-jewish-community-diminished-6-women-afterdeath-lucy-saul/> (accessed December 15, 2017).

6 Nmisr: "Quwwāt al-amn ta'zil anșār al-ikhwān al-muslimīn ba'd tasabbubihim bi-islām thalāth masīḥiyyīn bi-Ṭurah,” Nujūm Mișriyya, January 29, 2016, <https://www.nmisr.com/arab-news/egyptnews/ حوات-الأمن-تعزل-انصار -الأخوان-المسلمي (accessed November 1, 2017).

7 'Abd al-Hafīz, Șabrī. "al-Aqbāt yatazāharūn li-sti'ādatihā wa'l-muslimūn li-tasallumihā," Īlāf, May 7 , 2016, <http://elaph.com/Web/News/2016/5/1087240.html> (accessed November 1, 2017).

8 Ibid.

9 “Ā̄iziz tighayyir diyāntak fī Mașr, ibqà qābiln̄i,” al-Șabāhh, April 12, 2016, <http://www.elsaba7.com/ NewsPrint.aspx?Id=142416> (accessed November 1, 2017). 
Dual Identities / Masking (S. Guth)

1 English mask is from Middle French masque 'covering to hide or guard the face' (16c.), from Italian maschera, from Medieval Latin masca 'mask, specter, nightmare,' which is perhaps from Arabic maskharah 'buffoon, mockery,' from sakhira 'be mocked, ridiculed' - <etymonline.com> (as of 09Dec2017).

Page | 508

2 Quoted in: <http://www.venice-days.com/FILM.asp?id=9\&id_dettaglio=552\&lang=eng>.

3 Khadīja is a traditional Islamic name in reverence for the Prophet's first wife.

Satire (on YouTube Channels) (M. Mohamed)

1 yi?allish, on the other hand, is the common term among Egyptian youth for all kinds of verbal practices that stimulate laughter, like puns, parody, and irony. 